\title{
Sevanol and Its Analogues: Chemical Synthesis, Biological Effects and Molecular Docking
}

\author{
Olga A. Belozerova ${ }^{1, *,+}$, Dmitry I. Osmakov ${ }^{1,2,+} \oplus$, Andrey Vladimirov ${ }^{1}$, Sergey G. Koshelev ${ }^{1}$, \\ Anton O. Chugunov 1,3,4 ${ }^{\circ}$, Yaroslav A. Andreev 1,2 ${ }^{-}$, Victor A. Palikov ${ }^{5}$, Yulia A. Palikova ${ }^{5}$, \\ Elvira R. Shaykhutdinova ${ }^{5}$, Artem N. Gvozd ${ }^{6}$, Igor A. Dyachenko ${ }^{5}$, Roman G. Efremov ${ }^{1,3,4}$, \\ Vadim S. Kublitski ${ }^{1}$ and Sergey A. Kozlov ${ }^{1, *(1)}$ \\ 1 Shemyakin-Ovchinnikov Institute of Bioorganic Chemistry, Russian Academy of Sciences, \\ 117997 Moscow, Russia; osmadim@gmail.com (D.I.O.); andrej.vladimirov.1995@mail.ru (A.V.); \\ sknew@yandex.ru (S.G.K.); anton.chugunov@gmail.com (A.O.C.); shifter2007@gmail.com (Y.A.A.); \\ r-efremov@yandex.ru (R.G.E.); vkublitski@pharmabio.ru (V.S.K.) \\ 2 Institute of Molecular Medicine, Sechenov First Moscow State Medical University, 119991 Moscow, Russia \\ 3 National Research University Higher School of Economics, 101000 Moscow, Russia \\ 4 Moscow Institute of Physics and Technology (State University), Dolgoprudny, 141701 Moscow Oblast, Russia \\ 5 Branch of the Shemyakin-Ovchinnikov Institute of Bioorganic Chemistry, Russian Academy of Sciences, \\ 6 Nauki Avenue, 142290 Pushchino, Russia; viktorpalikov@mail.ru (V.A.P.); \\ yuliyapalikova@bibch.ru (Y.A.P.); shaykhutdinova@bibch.ru (E.R.S.); dyachenko@bibch.ru (I.A.D.) \\ 6 Federal State Budgetary Institution «Scientific Center of Biomedical Technologies of Federal Medical and \\ Biological Agency» (FSBI SCBT FMBA of Russia), 1 Svetlye Gory, Moscovskaya Oblast, \\ 143442 Krasnogorskiy Rayon, Russia; agvozd33@gmail.com \\ * Correspondence: o.belozyorova@gmail.com (O.A.B.); serg@ibch.ru (S.A.K.) \\ + These authors contributed equally to this work.
}

Received: 10 June 2020; Accepted: 21 July 2020; Published: 24 July 2020

\begin{abstract}
Among acid-sensing ion channels (ASICs), ASIC1a and ASIC3 subunits are the most widespread and prevalent in physiological and pathophysiological conditions. They participate in synaptic plasticity, learning and memory, as well as the perception of inflammatory and neurological pain, making these channels attractive pharmacological targets. Sevanol, a natural lignan isolated from Thymus armeniacus, inhibits the activity of ASIC1a and ASIC3 isoforms, and has a significant analgesic and anti-inflammatory effect. In this work, we described the efficient chemical synthesis scheme of sevanol and its analogues, which allows us to analyze the structure-activity relationships of the different parts of this molecule. We found that the inhibitory activity of sevanol and its analogues on ASIC1a and ASIC 3 channels depends on the number and availability of the carboxyl groups of the molecule. At the structural level, we predicted the presence of a sevanol binding site based on the presence of molecular docking in the central vestibule of the ASIC1a channel. We predicted that this site could also be occupied in part by the FRRF-amide peptide, and the competition assay of sevanol with this peptide confirmed this prediction. The intravenous (i.v.), intranasal (i.n.) and, especially, oral (p.o.) administration of synthetic sevanol in animal models produced significant analgesic and anti-inflammatory effects. Both non-invasive methods of sevanol administration (i.n. and p.o.) showed greater efficacy than the invasive (i.v.) method, thus opening new horizons for medicinal uses of sevanol.
\end{abstract}

Keywords: acid-sensing ion channel; sevanol; electrophysiology; molecular docking; nociception; analgesia; lignan; total synthesis 


\section{Introduction}

Pathological conditions, such as tissue damage, cancer and inflammation, are often accompanied by the acidification of the extracellular environment, which is a primary cause of pain in the sufferer. Acid-sensing ion channels (ASICs), members of the degenerin/epithelial $\mathrm{Na}^{+}$-channels family, are sensitive to even a slight decrease of the extracellular $\mathrm{pH}$ [1,2]. In mammals, four genes encode at least six ASIC isoforms: ASIC1a and ASIC 3 isoforms are the most studied channels, and they contribute substantially to different physiological processes and pathological conditions. ASIC1a is expressed throughout the central and peripheral nervous systems, and plays an important role in synaptic plasticity, learning and memory, as well as in ischemic processes and anxiety disorders [3-5]. ASIC3 is widely distributed in the peripheral nervous system and non-neuronal tissues, and is involved in the perception of acid-mediated inflammatory pain (both acute and chronic) [6,7], as well as pain from various mechanical stimuli $[8,9]$.

As a result, these channels are regarded as promising targets for the development of analgesic and anti-inflammatory drugs. Indeed, ASIC channels were shown to be inhibited for low-molecular weight compounds of various natures and may, therefore, be promising objects for the study of channels and the design of drugs. Amiloride (a potassium-sparing diuretic agent) inhibits all of the functional isoforms of ASICs $\left(\mathrm{IC}_{50}\right.$ of $\left.10-60 \mu \mathrm{M}\right)$ [10]. A-317567 non-selectively inhibits the ASIC currents $\left(\mathrm{IC}_{50}\right.$ of 2-30 $\left.\mu \mathrm{M}\right)$ [11]. Nonsteroidal anti-inflammatory drugs act on different isoforms of ASIC: ibuprofen and flurbiprofen inhibit the ASIC1a-containing channels ( IC $_{50}$ of $350 \mu \mathrm{M}$ ), whereas aspirin and diclofenac inhibit the ASIC3-containing channels (IC $5_{50}$ of 260 and $92 \mu \mathrm{M}$, respectively) [12]. Diarylamidines cause the non-specific inhibition of neuronal ASIC currents ( $\mathrm{IC}_{50}$ of $\left.0.3-40 \mu \mathrm{M}\right)[13,14]$. NMDA receptor channel blockers, such as memantine, IEM-2117 and 9-aminoacridine, inhibit ASIC1a in submillimolar concentrations [15]. Most of these compounds are applied in clinics, and they have all demonstrated analgesic, anti-inflammatory or neuroprotective effects in tests in vivo $[4,7,11]$. More effective inhibitory activity on ASIC1a and/or ASIC3 isoforms has been identified in peptide molecules from spider $[16,17]$, snake $[18,19]$ and sea anemone [20-23] venoms, but such animal toxins have not thus far been successfully rendered as medicinal drugs.

Sevanol, a lignan isolated from Thymus armeniacus, inhibited human ASIC3 channels with IC50 of $0.3 \mathrm{mM}$ and possessed pain relief activity [24]. The parenteral administration of sevanol $(0.01-10 \mathrm{mg} / \mathrm{kg}$ ) in mice significantly reversed Complete Freund's adjuvant (CFA) -induced thermal hyperalgesia and reduced the number of writhes in an acetic acid-induced writhing test [25]. An effective scheme of chemical synthesis for sevanol and the fragment making up half of its ((1S,2S)-1-\{[(2E)-3-(3,4-dihydroxyphenyl)prop-2-enoyl]oxy\}propane-1,2,3-tricarboxylic acid, according to IUPAC) was developed, and the biological activity of the synthetic compounds was confirmed in vitro as well as in vivo [26,27]. According to previous work [26], the biological activity of Sevanol's diastereomer decreased on $20 \%$ of the natural Sevanol activity in electrophysiological experiments.

The investigation of structure-activity relationships (SAR) is the one of the effective tools for understanding the ligand-receptor interaction and, consequently, for drug design. Here, we present an improved scheme for the synthesis of sevanol and its analogues, and demonstrate a correlation between the activity of the compounds and the number of free carboxyl groups, as well as other physico-chemical descriptors. The competition of sevanol with the RF-amide peptide for ASIC1a modulation, together with molecular modeling, allowed us to predict the presence of the sevanol molecule's binding site in the central vestibule of the channel. We also demonstrate for the first time that sevanol is effective as an analgesic and anti-inflammatory agent by non-invasive intranasal and, to a greater extent, oral administration. This opens up promising prospects for its use in medicine. 


\section{Results and Discussion}

\subsection{Chemistry}

\subsubsection{Sevanol Production}

In the present study, we tried to trace the correlation between the structure of the sevanol molecule (I) and its biological activity. We modified the carboxylic part of I and obtained sevanol derivatives: s788 (II), s590 (III) and epiphyllic acid EA (IV) (Figure 1).<smiles>O=C(O)C[C@@H](C(=O)O)C(OC(=O)C1=Cc2cc(O)c(O)cc2[C@@H](c2ccc(O)c(O)c2)C1C(=O)OC(C(=O)O)C(C(=O)O)C(=O)O)C(=O)O</smiles>

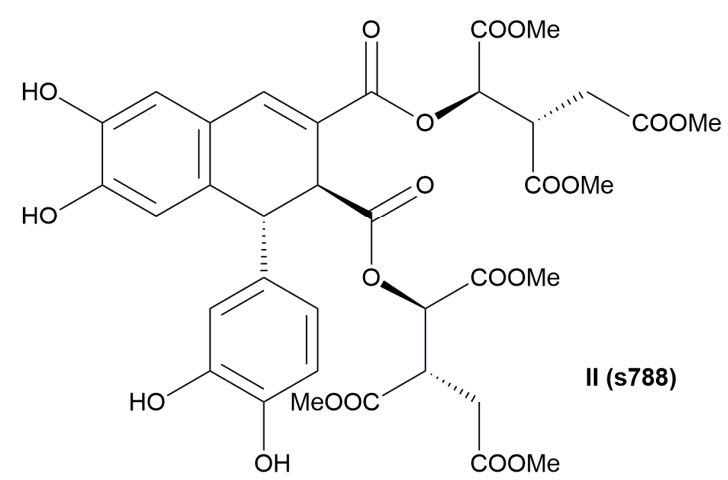<smiles>CCCCCCCCCC(=O)OC(CC(=O)O)C(=O)OC(=O)C1=Cc2cc(O)c(O)cc2[C@H](c2ccc(O)c(O)c2)C1C(=O)O</smiles>

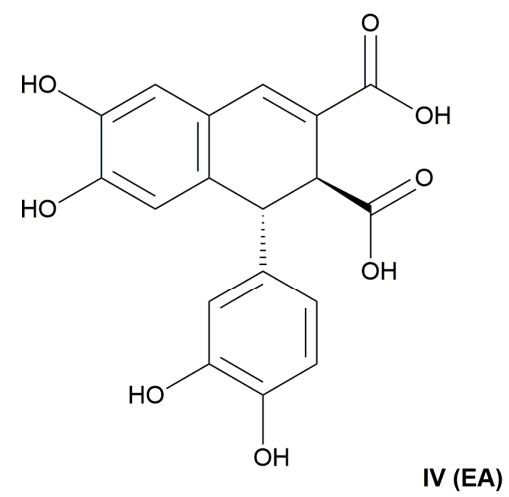

Figure 1. Sevanol and its analogues: I-sevanol; II-sevanol with methylated carboxylic groups; III—sevanol shortened by two acetic acid groups; IV—epiphyllic acid.

The synthesis of sevanol (I) was completed based on the method described previously [27]. The synthetic path included the parallel synthesis of two molecules: the t-butyl isocitrate $\mathbf{1}$ and the suitably protected caffeic acid 2 (Scheme 1). The method of obtaining the intermediate 4 included removing protecting groups (PG) from the phenolic hydroxyls of 3. Our careful search for the optimal protecting group has been discussed elsewhere [27].

The first branch of the total synthesis of sevanol (I) included the preparation of a suitably protected caffeic acid derivative 2 (Scheme 1). However, even though methoxymethyl acetal (MOM) seemed quite suitable as a protecting group before, the deprotection of caffeic isocitrate ester 3a using a mixture of trifluoroacetic acid (TFA) and $\mathrm{H}_{2} \mathrm{O}$ in ratio 4:1 gave the key intermediate 4 with a moderate yield of $53 \%$. Moreover, in order to produce MOM-protected caffeic acid 2a, the step of the alkylation of the 3,4-dihydroxybenzaldehyde proved problematic and we encountered issues, such as poor yield due to high impurity formation and the reaction tarring. Therefore, we attempted to improve the yield by changing the protective group to acetyl (Ac), as was described in [28]. Commercially available caffeic acid was carefully treated with five equivalents of $\mathrm{Ac}_{2} \mathrm{O}$ in the presence of ten equivalents of pyridine (Py) at $-20^{\circ} \mathrm{C}$. The reaction was stirred over $16 \mathrm{~h}$ at room temperature. The resulting product $2 \mathrm{~b}$ was 
isolated using recrystallization as a powder with a $91 \%$ yield. The corresponding acid chloride $2 \mathrm{c}$ was obtained using 1.2 eq. of thionyl chloride and toluene as a solvent in the presence of a catalytic amount of dimethylformamide (DMF). The reaction was completed after four hours at $100{ }^{\circ} \mathrm{C}$. Thus, we significantly increased the yield of 2 from $53 \%$ to $91 \%$ and simplified the purification of the desired product 2.
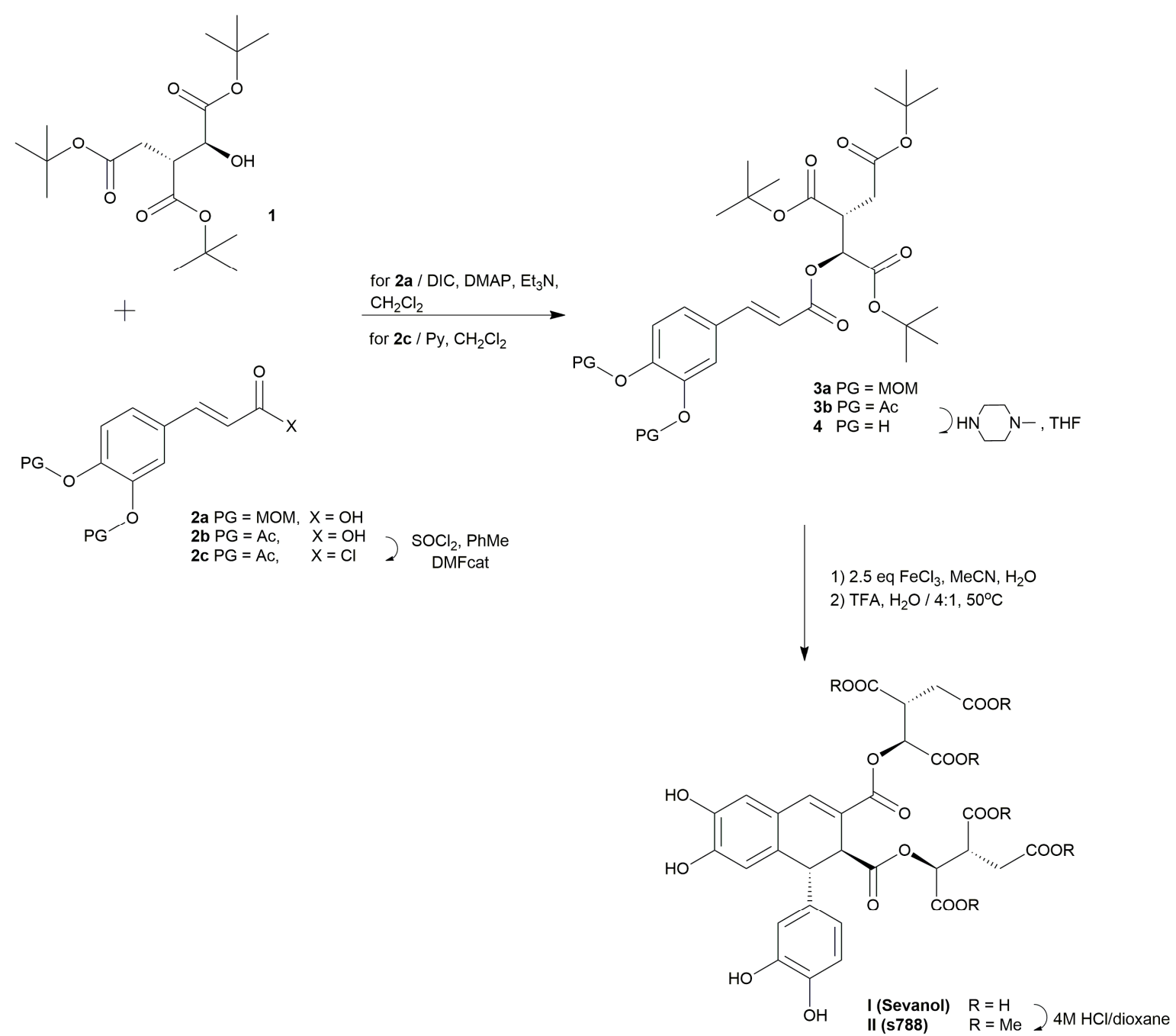

Scheme 1. Total synthesis of sevanol (I) and a sevanol derivative (II) with methylated acetic acid groups.

The second branch of the total synthesis of sevanol was devoted to the synthesis of the tri-t-butyl ester of isocitric acid (1). According to our initial work describing the total synthesis of sevanol I, the compound 1 was obtained according to the method described [29] with an overall yield of 17\%. However, we decided to modify it in order to improve the efficiency of our synthetic pathway of sevanol (I) by decreasing the number of stages and increasing the total yield of $t$-butyl isocitrate $\mathbf{1}$ (Scheme 2). The pathway reported by Calo et al. started from (L)-malic acid (5) and contained seven synthetic steps. The initial reaction medium remained the same as published in the original source, but the reaction time increased from $24 \mathrm{~h}$ to $72 \mathrm{~h}$ at room temperature. As a result, the molecule 6 was obtained with an $83 \%$ yield. The interaction of (L)-malic acid (5) with compound 6 led to the formation of the bis-t-butyl ester of malic acid (7) with a $53 \%$ yield based on the published method. After decreasing the reaction temperature from room temperature to $0{ }^{\circ} \mathrm{C}$ and increasing the 2-t-butyl-1,3-diisopropylisourea 6 from three to five equivalents, we found that we could increase the yield of 7 from $53 \%$ to $71 \%$ on this step. The four steps, following [29], yielded compound 1 with a 17\% overall yield. According to data in the 
literature, unfunctionalized compounds such as allyl bromide, methyl bromide, benzyl bromide and others were used as alkylating reagents for the bis-t-butyl ester of (L)-malic acid 7 [30,31]. Subsequently, these radicals underwent transformation in order to obtain functional groups based on them. In order to reduce the number of steps to afford the target compound 1, we used the moiety of acetic acid, i.e., $t$-butyl bromoacetate $\left(\mathrm{BrCH}_{2} \mathrm{COO} t \mathrm{Bu}\right)$ as an alkylating reagent for the transformation of molecule 7 in the desired alcohol 1 (Scheme 2). Initially, we attempted to perform the synthesis using two equivalents of LDA and one equivalent of $t$-butyl bromoacetate at $-78^{\circ} \mathrm{C}$. However, the yield of the reaction was low (19\%), even though the desired product 1 appeared. Therefore, we decided to increase the amount of metal reagent to 2.5 equivalents and the alkylating reagent to 1.5 equivalents. The adjustments made to the synthesis conditions allowed us to double the reaction yield to $53 \%$. Thus, it became possible to produce the $t$-butyl ester of isocitric acid (1) in one step. The optimum medium of the last step of the first synthetic approach was the usage of 1.5 equivalents of the alkylating reagent $\mathrm{BrCH}_{2} \mathrm{COO} t \mathrm{Bu}$ and 2.5 equivalents of BuLi as the metal reagent at $-78^{\circ} \mathrm{C}$ for $3 \mathrm{~h}$.

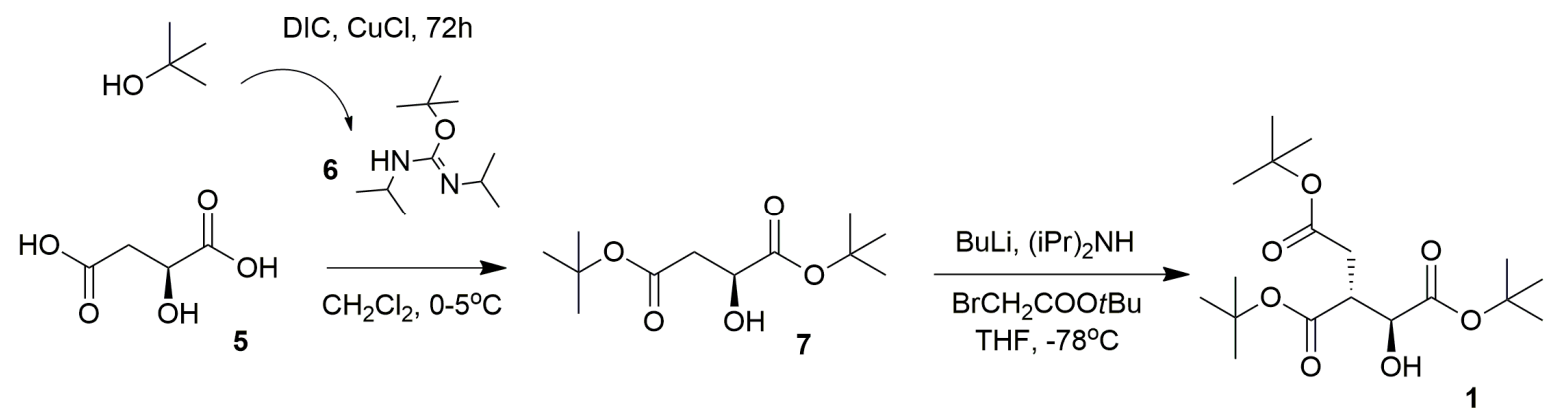

Scheme 2. The synthesis of the $t$-butyl ester of isocitric acid (1).

As a result, the key intermediate 1 was obtained with a 53\% yield on the step. The reduction in the number of steps from seven to three led to a decrease in the loss of intermediates during the intermediate reactions, and accordingly, to an increase in the overall yield of the branch of the synthesis of compound 1 from $17 \%$ to $36 \%$.

As mentioned above, the main strategy for the total synthesis of sevanol I (Scheme 1) was based on the condensation of two key intermediates 1 and 4 . The acylation of $t$-butyl isocitrate 1 with Ac-protected caffeic acid chloride (2c) was performed in dichloromethane in the presence of pyridine as a base, and afforded the compound $3 \mathbf{b}$ with a $84 \%$ yield (Scheme 1 ). The further deacetylation of compound $\mathbf{3 b}$ was carried out with $N$-methylpiperazine in tetrahydrofuran (THF), and led to key intermediate 4 . The yield on the deprotection step was $96 \%$. Thus, we achieved a more optimized route to produce key intermediate 4 . Due to the use of acetyl protecting groups for the phenolic hydroxyls of intermediates 2 and 3, the overall yield of preparation 4 was significantly increased from $7 \%$ to $30 \%$ compared to the method we described earlier [27].

The crucial coupling step of compound 4 was carried out according to the procedure we described previously [27]. The optimal reaction medium was carefully selected, and included the dimerization of compound 4 with 2.5 equivalents of iron (III) chloride in acetonitrile in the absence of light at $5{ }^{\circ} \mathrm{C}$ for $2 \mathrm{~h}$. After treating the resulting intermediate with $80 \%$ aqueous TFA for $1 \mathrm{~h}$ at $50{ }^{\circ} \mathrm{C}$, a crude deprotected substance of the target sevanol I was identified by ${ }^{1} \mathrm{H}$ NMR spectra. Chromatography on a semi-preparative HPLC reverse-phase column using $\mathrm{MeCN}-\mathrm{H}_{2} \mathrm{O}$ as eluents, followed by lyophilization, gave sevanol I as a mixture of diastereomers in a ratio of 1:3 (isosevanol:sevanol) with a 39\% yield.

Summarizing the stage modifications above, we achieved a significant increase in the overall yield of the total synthesis of sevanol (I) from 3\% [27] to $8 \%$, and reduced the number of synthetic procedures to nine steps. 


\subsubsection{Synthesis of the Derivatives of Sevanol}

The carboxylic acid functional group is an important structural part of many scaffolds used in drugs. The acidity, high water solubility, and ability to establish electrostatic interactions and hydrogen bonds make it highly attractive for its capacity to bind to protein targets [32]. We modified the structure of sevanol I by protecting the carboxylic groups with methyl in order to check whether these functional groups were involved in the binding site in ASICs. We produced a methyl ester of sevanol (s788) (II) by protecting it with methyl groups directly after the completion of the main synthesis of sevanol I according to Scheme 1. The compound I isolated and lyophilized after the last step of the total synthesis of sevanol I described above was dissolved in $4 \mathrm{M} \mathrm{HCl} / \mathrm{MeOH}$ and stored at $-20^{\circ} \mathrm{C}$ for $72 \mathrm{~h}$. The reaction mixture was carefully evaporated and purified on silica gel to afford the compound II (s788) with a 97\% yield. The phenolic hydroxyl groups remained unprotected.

We also examined a sevanol derivative by reducing the number of carboxylic acid groups, based on the assumption that the inhibitory effect could weaken due to the reduction of active functional groups. The compound III (s590) was obtained according to protocol described above for producing sevanol molecule I. However, the condensation of acetyl-protected acid chloride $2 \mathrm{c}$ with (L)-malic acid 7 possessing two $t$-butyl protected carboxylic acid groups, and gave the key intermediate 8 with an $81 \%$ yield (Scheme 3). Compound 8 underwent the removal of protective groups using $n$-methylpiperazine, followed by dimerization in the same reaction medium as sevanol (I). After treatment with $80 \%$ aqueous TFA and purification on a semi-preparative HPLC reverse-phase column, followed by lyophilization, the target sevanol derivative III (s590) was obtained with an overall yield of $17 \%$.

The synthesis of compound IV (EA) has already been reported in the literature [33]. According to this work, epiphyllic acid (EA) (IV) was obtained as a co-product of the condensation reaction of caffeic acid in order to produce americanol and isoamericanol in the presence of horseradish peroxidase (HRP) in a phosphate buffer containing $18 \%$ 1,4-dioxane and $\mathrm{H}_{2} \mathrm{O}_{2}$. We performed the synthesis of IV (EA) by a new approach based on the procedure developed for sevanol (I) production (Scheme 4). Thus, commercially available caffeic acid was transformed into an ethyl ester of caffeic acid $\mathbf{1 0}$ in EtOH in the presence of a catalytic amount $\mathrm{H}_{2} \mathrm{SO}_{4}$ under reflux [34]. After the treatment with $\mathrm{NaHCO}_{3}$ and evaporation, the desired ethyl caffeate 10 was obtained with an $89 \%$ yield. The oxidative coupling of monomer 10 was performed using the conditions described for the preparation of $t$-butyl protected 9,10-diisocitryl ester of epiphyllic acid (sevanol) I [27]. Thus, the diethyl ester of epiphyllic acid 11 was produced using 2.5 equivalents of iron (III) chloride in acetonitrile in the absence of light at $5{ }^{\circ} \mathrm{C}$ for two hours, with a $37 \%$ yield. We tried to deprotect 11 by base hydrolysis with $5 \mathrm{M} \mathrm{NaOH}$ at room temperature. However, the reaction mixture underwent tarring, and it was almost impossible to isolate the target molecule IV (EA). Therefore, we attempted to perform the hydrolysis of $\mathbf{1 1}$ in an acidic medium using $4 \mathrm{M} \mathrm{HCl}$ /dioxane in the presence of $\mathrm{H}_{2} \mathrm{O}$, followed by purification on a semi-preparative HPLC reverse-phase column and lyophilization. This chosen reaction condition clearly led to the formation of epiphyllic acid IV (EA) with a $35 \%$ yield on this step.

As a result, a series of sevanol derivatives were designed. All of the compounds, including novel molecules such as II (s788) and III (s590), were characterized by NMR spectroscopy and high resolution mass spectrometry (HRMS). 
<smiles>CC(C)(C)OC(=O)CC(O)C(=O)OC(C)(C)C</smiles><smiles>CC(=O)Oc1ccc(/C=C/C(=O)Cl)cc1OC(C)=O</smiles><smiles>CC(C)(C)[13C](=O)[O-]</smiles><smiles>CC(=O)Oc1ccc(/C=C/C(=O)O[C@@H](CC(=O)OC(C)(C)C)C(=O)OC(C)(C)C)cc1OC(C)=O</smiles>
$\mathrm{HN}^{\mathrm{N}}-, \mathrm{THF}$

1) 2.5 eq $\mathrm{FeCl}_{3}, \mathrm{MeCN}, \mathrm{H}_{2} \mathrm{O}$ 2) TFA, $\mathrm{H}_{2} \mathrm{O} / 4: 1,50^{\circ} \mathrm{C}$<smiles>CC(C)(C)OC(=O)CC(OC(=O)/C=C/c1ccc(O)c(O)c1)C(=O)OC(C)(C)C</smiles>

9

Scheme 3. Total synthesis of epiphylic acid ester with (L)-malic acid residue III.<smiles>CCOC(=O)/C=C/c1ccc(O)c(O)c1</smiles>

1) $\mathrm{FeCl}_{3}, \mathrm{MeCN}, \mathrm{H}_{2} \mathrm{O}$

2) $4 \mathrm{M} \mathrm{HCl} /$ dioxane, $\mathrm{H}_{2} \mathrm{O}, 50^{\circ} \mathrm{C}$<smiles>[R]OC(=O)C1=Cc2cc(O)c(O)cc2[C@H](c2ccc(O)c(O)c2)C1C(=O)O[R]</smiles>

IV (EA) $\mathrm{R}=\mathrm{R}=\mathrm{H}$

Scheme 4. Synthesis of epiphyllic acid IV.

\subsection{ASIC1a and ASIC3 Inhibitory Activity of Sevanol and Its Analogues}

Testing the activity of synthetic sevanol (s706) (as a mixture of $75 \%$ of sevanol and $25 \%$ of isosevanol) and its analogues (s590, EA, and s788) was carried out by the standard two-electrode voltage clamp method on X. laevis oocytes expressing rat ASIC1a and ASIC3 channels. The activation of the channels was performed using a rapid change of the solution from conditioning $\mathrm{pH} 7.4$ to a solution with pH 5.5. Sevanol and its two analogues, s590 and EA, inhibited ASIC1a and ASIC3 channels. The effect reached a 100\% current block, and was reversible. s788 did not demonstrate any activity in these channels. The dose-response curve and the value of the half-maximal effective 
concentrations $\left(\mathrm{IC}_{50}\right)$ for both the ASIC1a and ASIC3 isoforms clearly demonstrated the correlation of the channels' inhibitory effect with the number of carboxyl groups of the compounds (Figure 2).

A

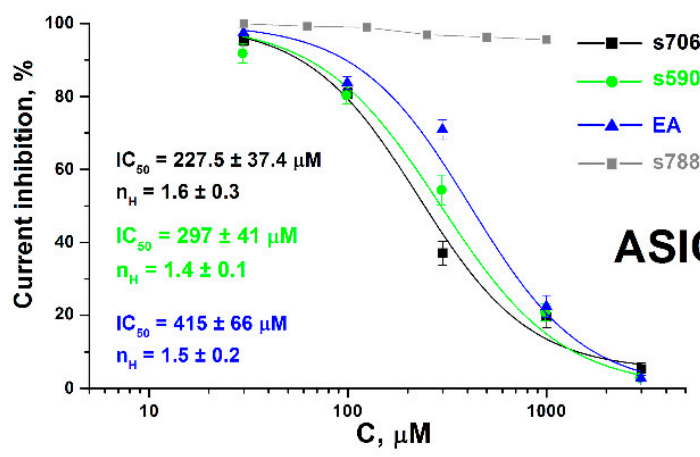

C

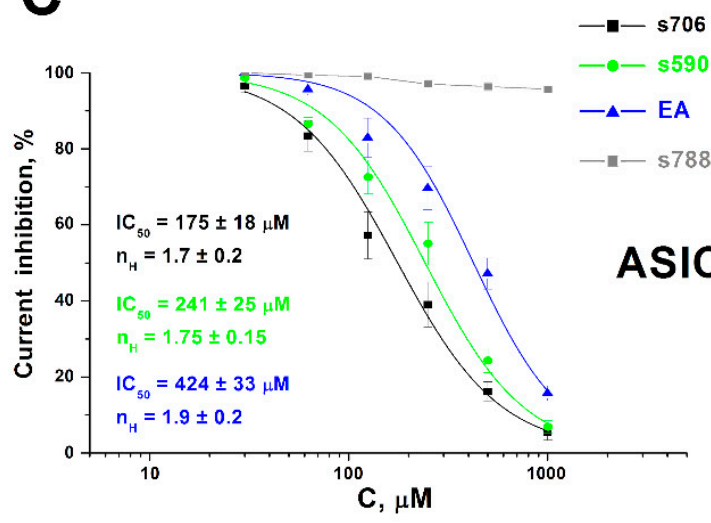

B

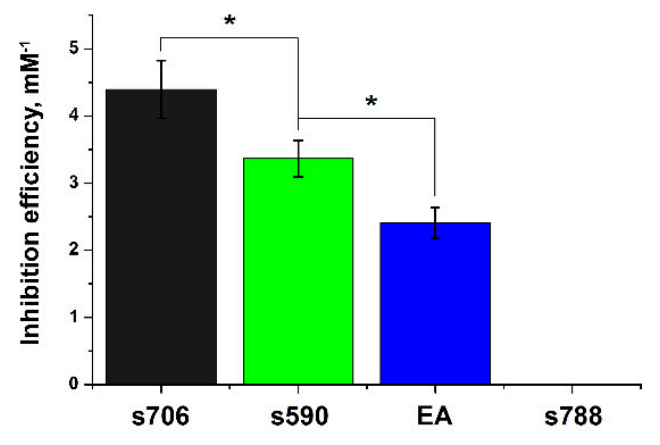

D

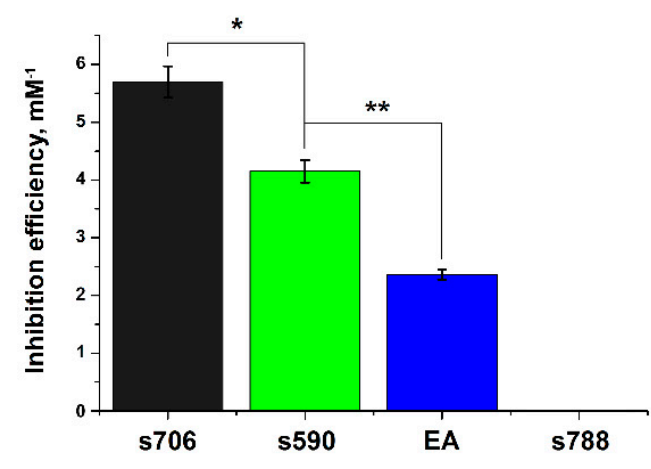

Figure 2. The inhibitory activity of sevanol (s706) and its analogues. Currents were elicited by a drop from $\mathrm{pH} 7.4$ to 5.5 ; the holding potential was $-50 \mathrm{mV} ;(\mathbf{A}, \mathbf{C})$ are dose-response curves for s706, $\mathbf{s 5 9 0}$ and EA inhibitory effects on ASIC1a and ASIC3 channels, respectively; (B,D) are reciprocal $\mathrm{IC}_{50}$ values for s706, s590 and EA inhibitory effects on ASIC1a and ASIC3 channels, respectively. The data were fitted by the logistic equation. Each point is the mean \pm SEM of 5-6 measurements. ${ }^{*} p<0.05,{ }^{* *} p<0.005$.

We computed the hydrophobic/hydrophilic and electrostatic properties of the studied molecules and their distributions over the molecular surfaces of the compounds. All of them exhibited perfect correlation $(\geq 0.9)$ with $\mathrm{IC}_{50}$ (see Supplementary Table S1), suggesting that each carboxyl group truly contributes to the inhibiting activity of the ASICs, and the presence at least two of them was essential. Therefore, s706, which has the largest number of carboxyl groups (6), showed a stronger and significantly distinguishable inhibitory effect. This difference in the effectiveness of molecules was more clearly manifested for the ASIC3 channel's activation by acidification: s706 showed a greater apparent affinity than s590 (calculated $\mathrm{IC}_{50}$ values $175 \pm 18 \mu \mathrm{M}$ versus $241 \pm 25 \mu \mathrm{M}, p=0.016$, respectively); s590, in turn, showed a greater apparent affinity than epiphyllic acid EA $(241 \pm 25 \mu \mathrm{M}$ versus $424 \pm 33 \mu \mathrm{M}$, $p=0.002$ ). Compound II, s788, has as many carboxyl groups as sevanol, but all of them are blocked by methyl groups. Sevanol was 1.3 times more effective in inhibiting ASIC3 than ASIC1a. The same can be observed for s590. EA acted equally on the ASIC1a and ASIC3 channels. As a result, it can be argued that sevanol and its two truncated analogs inhibit both subtypes of acid-sensing channels; however, the removal of each pair of free carboxyl groups decreased the activity.

It is known that RF-amide peptides produce a potentiating effect on ASIC1a by inhibiting the channel's desensitization in the presence of protons (during acidic stimulation). The peptides exhibit this effect both in the case of desensitization following the activation of the channels and in the case of 
steady-state desensitization, when the channels cease to respond to the acid stimulus bypassing the activation stage $[35,36]$. Using molecular docking and site-directed mutagenesis, it has been shown that RF-amide peptides are most likely to bind to ASICla in the central vestibule of the chicken channel [37]. We examined the inhibitory effect of sevanol on the ASIC1a channel activated by $\mathrm{pH} 5.5$ in the presence of $200 \mu \mathrm{M}$ FRRFa peptide (Phe-Arg-Arg-Phe-amide), and showed that sevanol and the peptide compete for the binding site. Figure 3A shows that, in the presence of the peptide, the characteristic form of the current with delayed desensitization persists upon co-application with sevanol. The peptide worsened the effectiveness of the inhibitory action of sevanol on the channel by 1.5 times, and reduced the Hill coefficient (Figure 3). Thus, it can be assumed that the binding site of sevanol also lies in the region of the central vestibule.

A

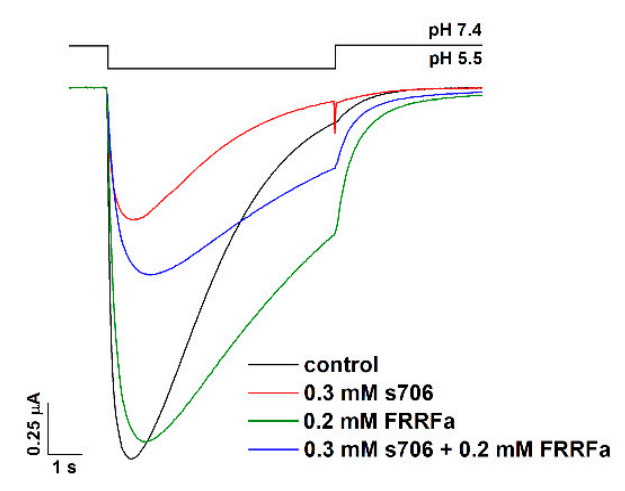

B

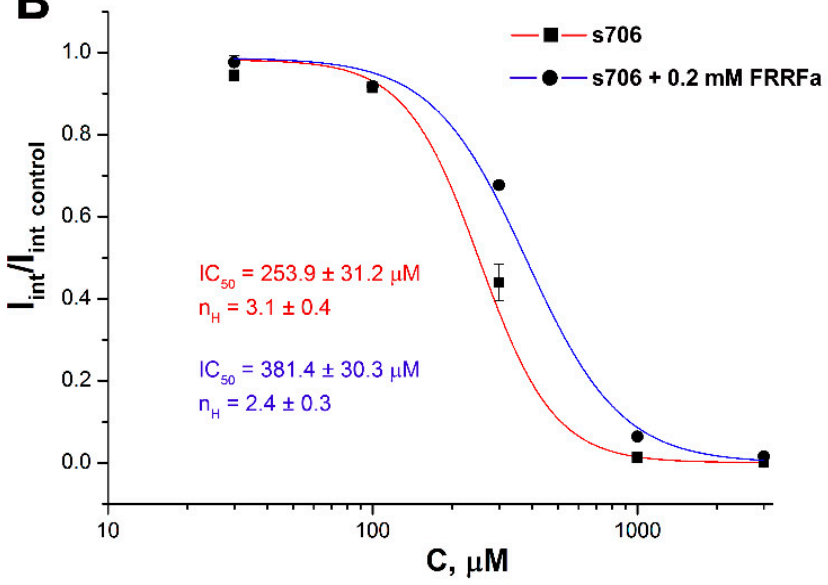

Figure 3. Comparison of sevanol (s706) and the Phe-Arg-Arg-Phe-amide peptide (FRRFa) effects on the ASIC1a current. (A) Representative traces of $\mathrm{pH}$ 5.5-evoked currents of ASIC1a alone (black trace) and of ASIC1a with a $15 \mathrm{~s}$ pre-incubation of $300 \mu \mathrm{M}$ s706 (red trace), $200 \mu \mathrm{M}$ FRRFa (green trace), or a mixture of $300 \mu \mathrm{M}$ s706 and $200 \mu \mathrm{M}$ FRRFa (blue trace). (B) Dose-response ASIC1a inhibitory curves for s706 alone (red line) and for s706 in the presence of $200 \mu \mathrm{M}$ FRRFa (blue line), determined for integral currents. Data were fitted by the logistic equation. Data are presented as mean \pm SEM $(n=5)$.

\subsection{Molecular Docking}

Taking into account the conclusion about the occupation of the central pore, we performed a molecular docking of sevanol and s788 into a model of the closed rASIC1a, and focused on the central vestibule, virtually excluding the classic acidic pocket from consideration (see Methods). The top 20 sevanol-rASIC1a docking solutions were found in the central vestibule, approximately on the channel's axis (according to Autodock scoring, the calculated free energy of binding is $\Delta \mathrm{G}_{\text {binging }}=$ $-7.01 \pm 0.12 \mathrm{kcal} / \mathrm{M}$ ), not occupying the vestibule's side cavities (Figure 4). Our electrophysiological experiments show that sevanol and FRRFa compete to a small extent for the binding site, and this fact is confirmed by the docking results. Recently, FRRFa has been predicted to bind in the side cavities of the vestibule, coordinated by three glutamic acid and one valine residues that have been confirmed to be important for this binding [37]. Sevanol, as a highly acidic molecule, is unlikely to occupy the same site due to a presumed strong electrostatic repulsion. Most likely, the sevanol and FRRFa sites in the central vestibule partially overlap (Figure 4B). This was confirmed by the concurrent binding between these compounds in electrophysiology. 

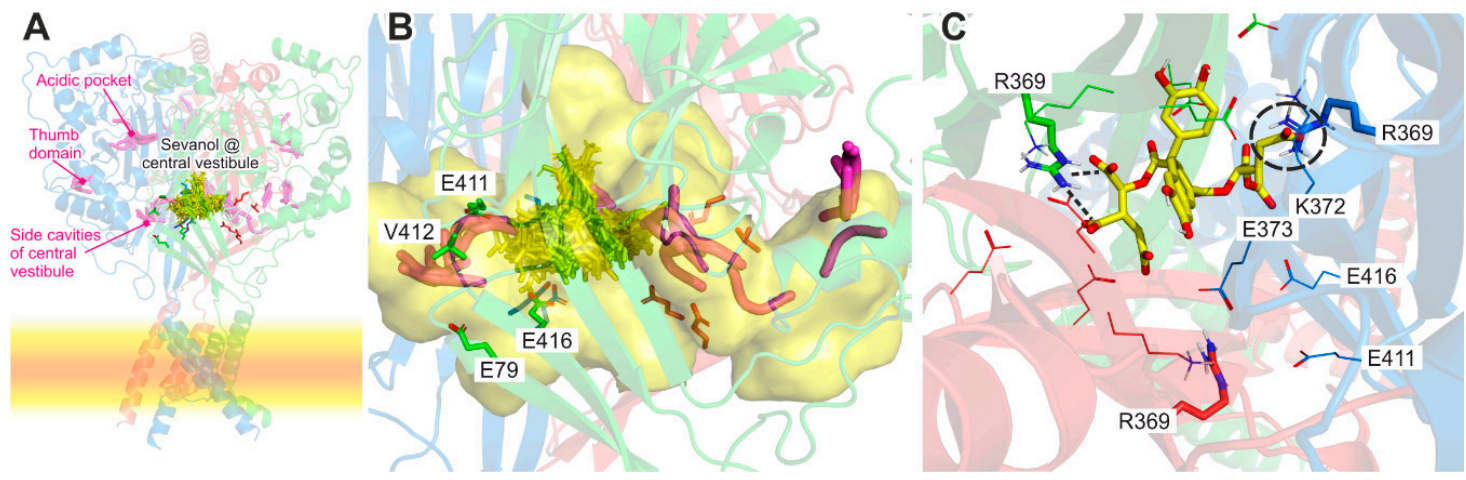

Figure 4. Sevanol docking into rASIC1a (A-C) (PDB ID 5WKU), and a comparison with FRRFa docking (A,B). (A) The semi-transparent cartoon shows the closed rASIC1a channel model; each subunit is individually colored, and the the membrane is schematically depicted with a yellow stripe. The yellow sticks represent 20 sevanol docking solutions inside the central vestibule. Magenta tubes depict the docking results for the FRRFa peptide (obtained from [37]), revealing three probable binding sites per subunit (the so-called acidic pocket, the pocket at the bottom of the thumb domain, and the central vestibule side cavities). (B) Close-up view of (A) with the central vestibule cavity shown as a semi-transparent yellow surface. Several channels' residues, which are important for FRRFa binding in the central vestibule (as confirmed by mutagenesis), are shown with sticks and subscribed. One can note the partial overlap of the sevanol and FRRFa binding sites. (C) The sevanol binding site (solution \#3) inside the central part of the vestibule (view from the top of the ASIC1 trimer). Arg369 is shown with sticks, other residues with lines. The probable salt bridges between the sevanol carboxyl groups and two Arg369 residues are depicted by dashed lines and a circle.

The presumed sevanol binding site includes three Arg 369 residues from the adjacent rASIC1a subunits. Sevanol probably forms at least two ionic bridges with these residues through its carboxyl moieties—one from the each 'branch' of the carboxyl groups. Molecular dynamics modeling and/or the further determination of the complex structure should reveal if it is possible to simultaneously form three ionic bridges. The molecular flexibility of the sevanol and ASIC1a molecules may permit such binding. Apart from Arg 369, three Lys 372 residues are also present in the binding site $(\approx 5 \AA$ 'above' arginines) and may electrostatically interact with sevanol (Figure 4C), although we did not observe this in our docking - sevanol typically neighbors them only by the hydroxyl groups of the polyphenolic part of the molecule. Besides the two 'rings' of positively charged residues, there are also three 'rings' of negatively charged glutamic acid residues: Glu 416 at the level of Arg 369, and Glu 411 and Glu 373 at the 'upper level' of Lys 372. The latter may somehow neutralize Lys 372 and leave only the possibility to interact with sevanol hydroxyl groups, while at the 'lower level', Arg 369 and Glu 416 optimally alternate in space, thus permitting sevanol accommodation in the binding site.

The docking of the compound s788 (not shown) reveals the obvious fact that this molecule, although it fits the binding site, cannot form ionic bridges with Arg 369 residues due to the absence of the carboxyl groups. Thus, Arg 369 residue seems to be critical for the binding of sevanol and its analogues and for antagonistic activity, which is the subject of the future mutagenesis validation. It is worth noting that Arg 369 has been confirmed to mediate the antagonistic effect of quercetin by mutagenesis to Ala [38]; therefore, this residue may be crucial for several ASIC1a antagonists.

\subsection{Analgesic Effects of Sevanol}

Sevanol was identified in the acidic extract of T. armeniacus as the low molecular weight natural molecule that reversibly inhibited both the transient and the sustained current of ASIC 3 channels and produced analgesia [24]. Synthetic sevanol exhibited the same analgesic properties after intravenous (i.v.) and intramuscular (i.m.) administration, as was reported for the natural compound [25]. As demonstrated above, sevanol keeps the best activity among analogues synthesized in this work, and 
therefore, it is the most promising molecule for further studies. For this reason, it was important to study its effect on animal models using various methods of administration. Both of the above-mentioned methods (i.v. and i.m.) are invasive and limit the potential interest to sevanol as a remedy. The analgesic effect of intranasally (i.n.) and orally (p.o.) administered sevanol was measured and compared with i.v. administration in in vivo models of visceral pain intensity after the intraperitoneal administration of acetic acid and CFA-induced inflammation.

The intraperitoneal administration of acetic acid provokes a constriction response that is considered the definitive measure of visceral pain intensity [39]. Animals were pretreated with synthetic sevanol before the acetic acid injection. The sevanol administration significantly reduced the number of writhes in all of these methods of administration (Figure 5A-C). I.v. and i.n. administration produced a statistically significant effect at doses higher than $0.1 \mathrm{mg} / \mathrm{kg}$, whereas p.o. administration was effective starting from a dose of $0.01 \mathrm{mg} / \mathrm{kg}$. All of the administration routes reduced the number of writhes by more than $50 \%$ at a dose of $1 \mathrm{mg} / \mathrm{kg}$. When applied i.n., sevanol could also reach the central nervous system and inhibit ASIC1a, the isoform broadly distributed in the brain, and, for example, indirectly influence the opioid system, resulting in a central analgesia, as was previously described for the ASIC1a inhibitors (PcTx1, lindoldhamine) [40,41]. However, in our experiments, no additional analgesic effect in comparison with i.v. administration was observed. Moreover, the weaker effect of i.n. administration could be the result of the slower distribution of sevanol from the nasal cavities to the peripheral nervous system of the abdomen.
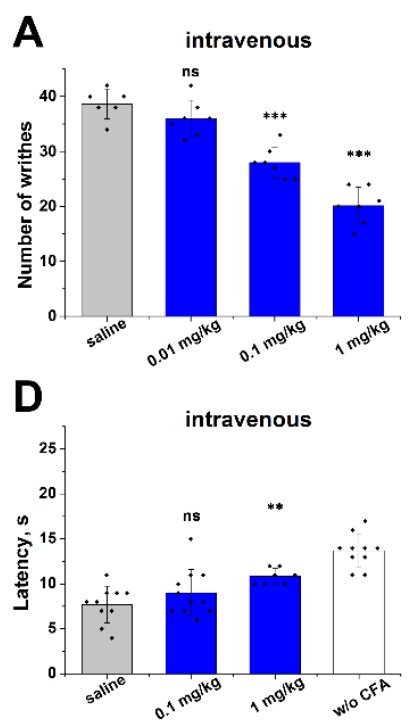

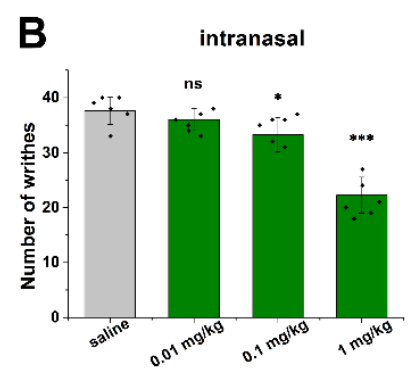

E

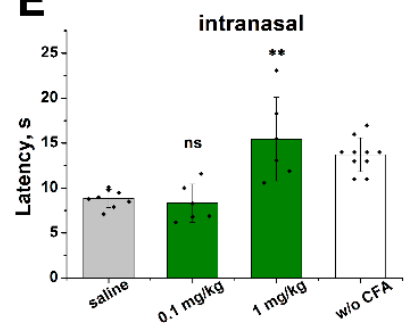

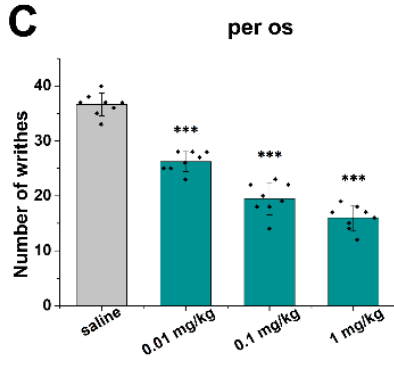

$\mathbf{F}$

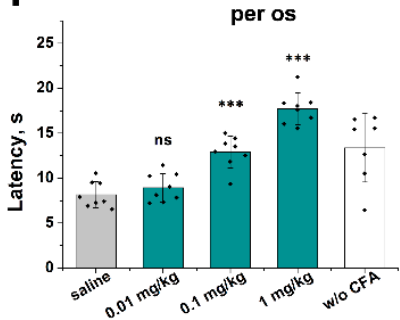

Figure 5. The analgesic and anti-inflammatory effects of sevanol following intravenous, intranasal and per os administration. The effect of sevanol on the acetic acid induced writhing $(\mathbf{A}-\mathbf{C})$ and on the mice withdrawal latency on a hot plate in the thermal hyperalgesia test after CFA injection (D-F) upon intravenous (A,D), intranasal (B,E) and oral (C,F) administration. Pretreating the mice with sevanol (30 min before testing) attenuated the response to the intraperitoneal administration of acetic acid, as estimated by the number of writhes in $30 \mathrm{~min}$ intervals, and significantly reversed CFA-induced thermal hyperalgesia prolonging the withdrawal latency for an inflamed hind paw placed on a hot plate. The results are presented as the mean \pm SD $(n=6-10)$. The $p$-values of the sevanol groups vs. the saline group are based on an analysis of variance and on Tukey's test; ${ }^{*} p<0.05,{ }^{* *} p<0.005$, $* * * \quad p<0.001$.

Sevanol showed anti-inflammatory properties in a CFA-induced thermal hyperalgesia test (Figure 5D-E). This effect reached statistical significance at a dose of $1 \mathrm{mg} / \mathrm{kg}$ both with i.v. and i.n. administration and, surprisingly, was more pronounced with p.o. administration (the effect was 
statistically significant at a dose of $0.1 \mathrm{mg} / \mathrm{kg}$ ). Moreover, a significant reduction in paw oedema was observed only when sevanol was administrated p.o. (Figure 6).

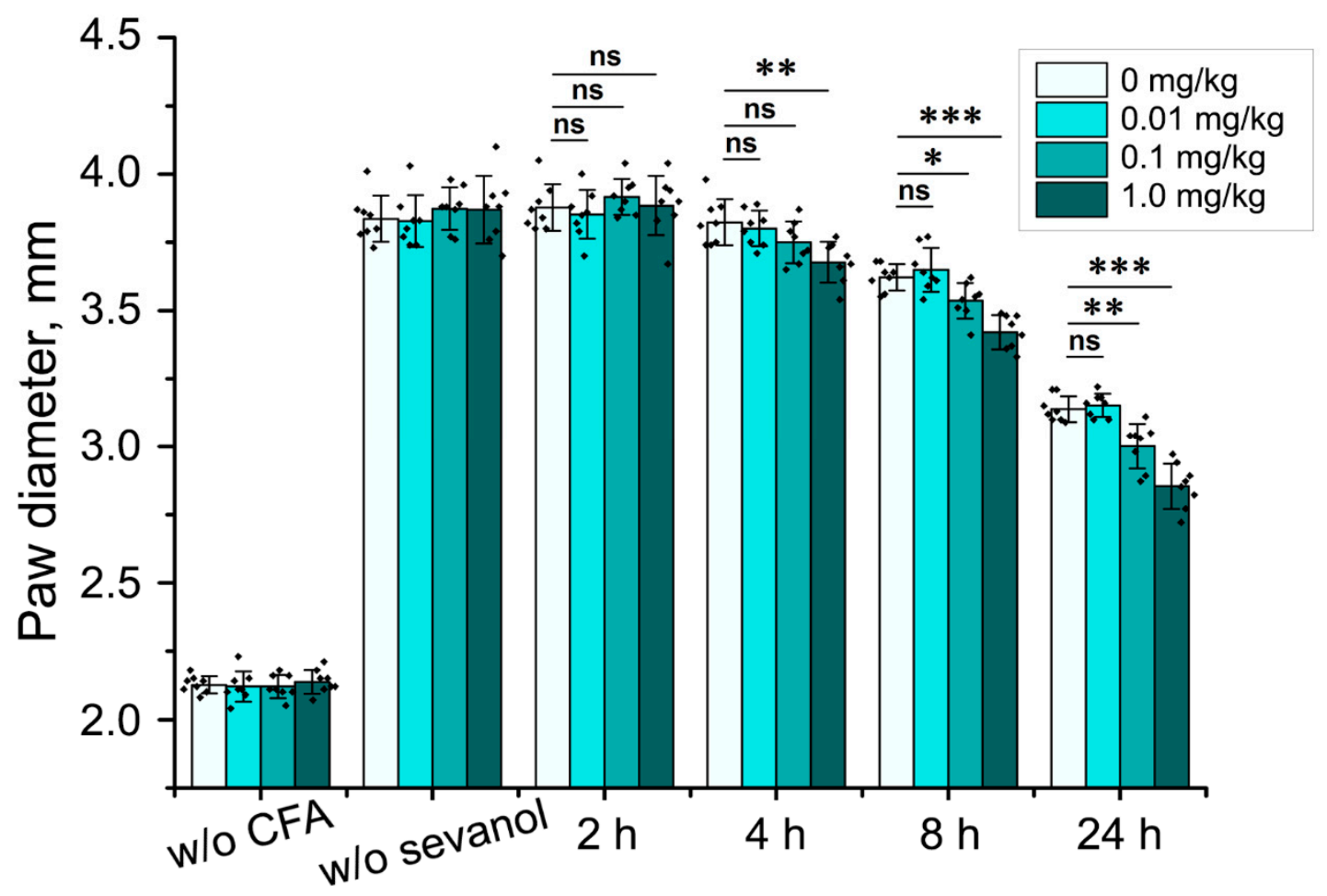

Figure 6. Anti-inflammatory effect (oedema reduction) of sevanol after per os (p.o.) administration. Paw oedema induced by CFA injection was estimated before the CFA and sevanol administration, and $2,4,8$ and $24 \mathrm{~h}$ after the p.o. administration of sevanol at different doses. Results are presented as the mean $\pm \mathrm{SD}(n=8) .{ }^{*} p<0.05,{ }^{* *} p<0.005,{ }^{* * *} p<0.001$ versus the saline group (ANOVA followed by a Tukey's test).

The effectiveness of orally administered sevanol in both tests overcame the effects of the other routes of administration, which may be explained by the partial bioconversion of sevanol during first pass metabolism into a more active metabolite. Most probably, this metabolite, together with sevanol, provided a 10-fold enhanced analgesic and anti-inflammatory effect. Therefore, sevanol can exhibit analgesic and anti-inflammatory properties with high efficiency after non-invasive methods of administration to the organism. That fact makes this molecule attractive for further drug development.

\section{Materials and Methods}

\subsection{Experimental General Information}

All of the reactions utilizing moisture-sensitive reagents were performed under an inert atmosphere. All of the commercially obtained reagents were used without further purification. Thin-layer chromatography (TLC) was carried out on pre-coated plates (silica gel 60, $\mathrm{F}_{254}$, Fluka), and the spots were visualized with UV and fluorescent lights, or by staining with phosphomolybdic acid stains. Column chromatography was performed on silica gel $(0.063-0.2 \mathrm{~mm} / 70-230$ mesh ASTM, MN Kieselgel). All of the NMR spectra were obtained on Bruker AVANCE III spectrometers (Bruker BioSpin, Germany) with proton operating frequencies of 300, 600 and $800 \mathrm{MHz}$. Chemical shifts are reported relative to residue peaks of $\mathrm{CDCl}_{3}\left(7.27 \mathrm{ppm}\right.$ for ${ }^{1} \mathrm{H}$ and $77.0 \mathrm{ppm}$ for $\left.13 \mathrm{C}\right)$, acetone (2.05 ppm for ${ }^{1} \mathrm{H}$ and $29.8 \mathrm{ppm}, 206.2 \mathrm{ppm}$ for $\left.{ }^{13} \mathrm{C}\right)$ and $\mathrm{D}_{2} \mathrm{O}\left(4.79 \mathrm{ppm}\right.$ for $\left.{ }^{1} \mathrm{H}\right)$. High-resolution mass spectra (HRMS) were measured on an Agilent 6224 TOF LC/MS System. 


\subsection{Syntheisis of tri-tert-butyl 1-hydroxypropane-1,2,3-tricarboxylate 1}

A solution of $2.5 \mathrm{M}$ BuLi in hexane $(121.2 \mathrm{mmol}, 48 \mathrm{~mL})$ was added dropwise to a solution of $n, n$-diisopropylamine $(121.2 \mathrm{mmol}, 17 \mathrm{~mL})$ in THF $(100 \mathrm{~mL})$ under nitrogen at $-50^{\circ} \mathrm{C}$. The mixture was stirred for $30 \mathrm{~min}$ at $-50{ }^{\circ} \mathrm{C}$. After the reaction cooled to $-78{ }^{\circ} \mathrm{C}$, a $t$-butyl ester of malic acid 7 ( $48.7 \mathrm{mmol}, 12 \mathrm{~g}$ ) dissolved in $40 \mathrm{~mL}$ THF was added dropwise, and the resulting solution was stirred for $20 \mathrm{~min}$. Subsequently, $t$-butyl bromoacetate $(73.1 \mathrm{mmol}, 10.6 \mathrm{~mL})$ in $20 \mathrm{~mL}$ THF was added dropwise over $10 \mathrm{~min}$ at $-78{ }^{\circ} \mathrm{C}$. The resulting mixture was stirred for three hours at $-20^{\circ} \mathrm{C}$. The progress of the reaction was controlled by TLC using EtOAC/hexane (1:9). After the completion of the reaction, the resulting mixture was quenched with $1 \mathrm{M} \mathrm{HCl}(200 \mathrm{~mL})$, extracted with EtOAc $(2 \times 70 \mathrm{~mL})$, dried over anhydrous $\mathrm{Na}_{2} \mathrm{SO}_{4}$, concentrated in vacuo and purified by column chromatography eluting with EtOAc/hexane (1:10) to give compound 1 as a colorless oil ( $9.15 \mathrm{~g}, 53 \%)$ : $\operatorname{Rf}(11 \%$, EtOAc/hexane) 0.33; ${ }^{1} \mathrm{H}$ NMR $\left(300 \mathrm{MHz}, \mathrm{CDCl}_{3}\right) \delta_{\mathrm{H}}: 4.21(1 \mathrm{H}, \mathrm{dd}, J=5.7,2.7 \mathrm{~Hz}), 3.31(1 \mathrm{H}, \mathrm{ddd}, J=8.6,6.2,2.7 \mathrm{~Hz}), 3.23$ $(1 \mathrm{H}, \mathrm{dd}, J=27.9,6.0 \mathrm{~Hz}), 2.76(1 \mathrm{H}, \mathrm{dd}, J=16.7,8.5 \mathrm{~Hz}), 2.52(1 \mathrm{H}, \mathrm{dd}, J=16.7,6.1 \mathrm{~Hz}), 9.29(9 \mathrm{H}, \mathrm{s}), 1.47$ (18H, s); HRMS: calcld [M + H] $]^{+} \mathrm{C}_{18} \mathrm{H}_{33} \mathrm{O}_{7} 361.2220[\mathrm{M}+\mathrm{H}]^{+}$found 361.2222.

\subsection{General Procedure for the Preparation of Substituted t-butyl Protected Caffeic Esters $3 b, 8$}

The alcohol (1: $5 \mathrm{~g}, 13.8 \mathrm{mmol} ; 5: 5 \mathrm{~g}, 20.3 \mathrm{mmol})$ was dissolved in $\mathrm{CH}_{2} \mathrm{Cl}_{2}(50 \mathrm{~mL})$, followed by the addition of pyridine ( $3 \mathrm{~b}: 18.8 \mathrm{mmol}, 1.45 \mathrm{~mL} ; 8: 26.4 \mathrm{mmol}, 2 \mathrm{~mL}$ ). The resulting reaction mixture was stirred for $15 \mathrm{~min}$ at $0-5{ }^{\circ} \mathrm{C}$ in an ice bath. A solution of the corresponding caffeic acid chloride $2 \mathrm{c}$ ( $3 \mathrm{~b}$ : $4.3 \mathrm{~g}, 15.2 \mathrm{mmol} ; 8: 6.3 \mathrm{~g}, 22.3 \mathrm{mmol})$ in $\mathrm{CH}_{2} \mathrm{Cl}_{2}(20 \mathrm{~mL})$ was added dropwise to the stirred mixture. The resulting solution was stirred under nitrogen for $2 \mathrm{~h}$ at room temperature, quenched with $1 \mathrm{M} \mathrm{HCl}$ $(30 \mathrm{~mL})$ and extracted with $\mathrm{CH}_{2} \mathrm{Cl}_{2}(2 \times 30 \mathrm{~mL})$. The combined organic layers were dried $\left(\mathrm{Na}_{2} \mathrm{SO}_{4}\right)$ and concentrated in vacuo. The residue was purified on silica gel, eluting with EtOAc/hexane (1:3) to afford the product ( $3 \mathrm{~b}$ white powder, $7.1 \mathrm{~g}, 84 \%$; 8 : colorless oil $8 \mathrm{~g}, 81 \%$ ).

(E)-tri-tert-butyl 1-((3,4-diacetoxystyryl)oxy)propane-1,2,3-tricarboxylate $3 \mathrm{~b}: \mathrm{Rf} \quad(33 \%$ EtOAc/hexane) 0.3; ${ }^{1} \mathrm{H}$ NMR $\left(600 \mathrm{MHz}, \mathrm{CDCl}_{3}\right) \delta_{\mathrm{H}}: 7.69(1 \mathrm{H}, \mathrm{dd}, J=8.4,1.9 \mathrm{~Hz}), 7.42(1 \mathrm{H}$, $\mathrm{d}, J=1.9 \mathrm{~Hz}), 7.37(1 \mathrm{H}, \mathrm{d}, J=1.9 \mathrm{~Hz}), 7.25(1 \mathrm{H}, J=8.4 \mathrm{~Hz}), 6.44(1 \mathrm{H}, \mathrm{d}, J=16.0 \mathrm{~Hz}), 5.30(1 \mathrm{H}, \mathrm{d}, J=$ $3.4 \mathrm{~Hz}), 3.44-3.48(1 \mathrm{H} . \mathrm{m}), 2.76(1 \mathrm{H}, \mathrm{dd}, J=16.7,9.8 \mathrm{~Hz}), 2.47(1 \mathrm{H}, \mathrm{dd}, J=16.8,5.0 \mathrm{~Hz}), 2.33(3 \mathrm{H}, \mathrm{s})$, $2.32(3 \mathrm{H}, \mathrm{s}), 1.51(9 \mathrm{H}, \mathrm{s}), 1.50(9 \mathrm{H}, \mathrm{s}), 1.48(9 \mathrm{H}, \mathrm{s}) ;{ }^{13} \mathrm{C} \mathrm{NMR}\left(600 \mathrm{MHz}, \mathrm{CDCl}_{3}\right): 170.0,168.7,167.5$, 167.5, 166.1, 164.9, 143.6, 143.2, 141.9, 132.6, 126.0, 123.5, 122.4, 117.7, 82.4, 81.4, 80.5, 71.8, 43.3, 33.3, 27.5, 20.1; HRMS: calcld $[\mathrm{M}+\mathrm{H}]^{+}$for $\mathrm{C}_{31} \mathrm{H}_{43} \mathrm{O}_{12} 607.2749[\mathrm{M}+\mathrm{H}]^{+}$found 607.2745.

(E)-di-tert-butyl 2-((3,4-diacetoxystyryl)oxy)succinate 8: Rf (33\% EtOAc/hexane) $0.3 ;{ }^{1} \mathrm{H} \mathrm{NMR}$ $\left(600 \mathrm{MHz}, \mathrm{CDCl}_{3}\right) \delta_{\mathrm{H}}: 7.69(1 \mathrm{H}, \mathrm{d}, J=16.0 \mathrm{~Hz}), 7.42(1 \mathrm{H}, \mathrm{dd}, J=8.4,2.1 \mathrm{~Hz}), 7.37(1 \mathrm{H}, \mathrm{d}, J=2.1 \mathrm{~Hz})$, $7.24(1 \mathrm{H}, \mathrm{d}, J=8.4 \mathrm{~Hz}), 6.45(1 \mathrm{H}, \mathrm{d}, J=16.0 \mathrm{~Hz}), 5.45(1 \mathrm{H}, \mathrm{dd}, J=7.9,4.7 \mathrm{~Hz}), 2.88-2.80(2 \mathrm{H}, \mathrm{m}), 2.32$ $(3 \mathrm{H}, \mathrm{s}), 2.32(3 \mathrm{H}, \mathrm{s}), 1.49(9 \mathrm{H}, \mathrm{s}), 1.47(9 \mathrm{H}, \mathrm{s}) ;{ }^{13} \mathrm{C} \mathrm{NMR}\left(600 \mathrm{MHz}, \mathrm{CDCl}_{3}\right): 167.9,167.5,167.5,164.9$, 143.4, 143.1, 141.9, 132.64, 126.02, 123.5, 122.3, 117.8, 82.2, 81.1, 68.8, 37.1, 27.5, 27.5, 20.1, 20.1; HRMS: $[\mathrm{M}+\mathrm{H}]^{+}$calcld for $\mathrm{C}_{25} \mathrm{H}_{33} \mathrm{O}_{10} 493.2068[\mathrm{M}+\mathrm{H}]^{+}$found 493.2065 .

\subsection{General Procedure for the Preparation of Substituted Caffeic Esters 4, 9}

Acetyl-protected caffeic acid ester ( $3 \mathrm{~b}: 5 \mathrm{~g}, 8.2 \mathrm{mmol} ; 8: 5 \mathrm{~g}, 10.2 \mathrm{mmol}$ ) was dissolved in THF $(50 \mathrm{~mL})$ under nitrogen. $N$-methylpiperazine $(4: 2 \mathrm{~mL}, 18 \mathrm{mmol} ; 8: 2.5 \mathrm{~mL}, 22.4 \mathrm{mmol})$ was added dropwise to the mixture at $0-5{ }^{\circ} \mathrm{C}$. The resulting solution was stirred for two hours at room temperature, quenched with $1 \mathrm{M} \mathrm{HCl}(30 \mathrm{~mL})$ and extracted with EtOAc $(30 \mathrm{~mL})$. The combined organic layers were dried $\left(\mathrm{Na}_{2} \mathrm{SO}_{4}\right)$ and evaporated in vacuo without heating. The residue was purified on silica gel, eluting with EtOAc/hexane (1:2) to give light-yellow oil (4: $4.1 \mathrm{~g}$, 96\%; 9: 3.4g 85\%).

(E)-tri-tert-butyl 1-((3-(3,4-dihydroxyphenyl)acryloyl)oxy)propane-1,2,3-tricarboxylate 4 [27]:

Rf (33\% EtOAc/hexane) 0.4; ${ }^{1} \mathrm{H}$ NMR $\left(600 \mathrm{MHz}, \mathrm{CDCl}_{3}\right) \delta_{\mathrm{H}}: 7.59(1 \mathrm{H}, \mathrm{d}, J=15.9 \mathrm{~Hz}), 7.04(1 \mathrm{H}, \mathrm{d}$, $J=1.8 \mathrm{~Hz}), 6.93-6.88(2 \mathrm{H}, \mathrm{m}), 6.22(1 \mathrm{H} \mathrm{d}, J=15.9 \mathrm{~Hz}) ,5.36(1 \mathrm{H}, \mathrm{d}, J=3.3 \mathrm{~Hz}), 3.54(1 \mathrm{H}, \mathrm{ddd}, J=9.7$, 
5.2, 3.4 Hz), $2.82(1 \mathrm{H}, \mathrm{dd}, J=16.8,9.7 \mathrm{~Hz}), 2.53(1 \mathrm{H}, \mathrm{dd}, J=16.8,5.1 \mathrm{~Hz}), 1.57(9 \mathrm{H}, \mathrm{s}), 1.56(9 \mathrm{H}, \mathrm{s}), 1.53$ (9H, s); HRMS: $[\mathrm{M}+\mathrm{H}]^{+}$calcld for $\mathrm{C}_{27} \mathrm{H}_{39} \mathrm{O}_{10}$ 523. $2537[\mathrm{M}+\mathrm{H}]^{+}$found 523.2539.

(E)-di-tert-butyl 2-((3,4-dihydroxystyryl)oxy)succinate 9:

$\operatorname{Rf}\left(33 \%\right.$ EtOAc/hexane) $0.25 ;{ }^{1} \mathrm{H}$ NMR $\left(600 \mathrm{MHz}, \mathrm{CDCl}_{3}\right) \delta_{\mathrm{H}}: 7.53(1 \mathrm{H}, \mathrm{d}, \mathrm{J}=15.9 \mathrm{~Hz}), 7.00(1 \mathrm{H}, \mathrm{d}$, $\mathrm{J}=1.7 \mathrm{~Hz}), 6.87(1 \mathrm{H}, \mathrm{dd}, \mathrm{J}=8.2,1.8 \mathrm{~Hz}), 6.84(1 \mathrm{H}, \mathrm{d}, \mathrm{J}=8.2), 6.71(1 \mathrm{H}, \mathrm{br} \mathrm{s}, \mathrm{OH}), 6.28(1 \mathrm{H}, \mathrm{br} \mathrm{s}, \mathrm{OH})$, $6.17(1 \mathrm{H}, \mathrm{d}, \mathrm{J}=15.9 \mathrm{~Hz}), 5.45(1 \mathrm{H}, \mathrm{dd}, \mathrm{J}=6.7,5.8 \mathrm{~Hz}), 2.89-2.84(2 \mathrm{H}, \mathrm{m}), 1.52(9 \mathrm{H}, \mathrm{s}), 1.49(9 \mathrm{H}, \mathrm{s}) ;{ }^{13} \mathrm{C}$ NMR $\left(600 \mathrm{MHz} \mathrm{CDCl}_{3}\right)$ ) : 168.5, 165.9, 146.2, 145.9, 143.7, 126.7, 121.9, 114.9, 113.9, 113.4, 82.8, 81.6, 68.5, 37.1, 27.5, 27.5; HRMS: [M + H]+ calcld for $\mathrm{C}_{21} \mathrm{H}_{29} \mathrm{O}_{8} 409.1857$ [M + H]+ found 409.1861.

\subsection{Synthesis of Sevanol I}

A solution of cinnamate $4(4 \mathrm{~g}, 7.76 \mathrm{mmol})$ in $\mathrm{MeCN}(40 \mathrm{~mL})$ was stirred at $5{ }^{\circ} \mathrm{C}$ in the absence of light while a solution of $\mathrm{FeCl}_{3}(3.1 \mathrm{~g}, 19.2 \mathrm{mmol})$ in $\mathrm{H}_{2} \mathrm{O}(30 \mathrm{~mL})$ was added dropwise. The dark green reaction mixture was stirred for $2 \mathrm{~h}$ at $5{ }^{\circ} \mathrm{C}$ in the absence of light. The resulting mixture was carefully diluted with $0.1 \mathrm{M} \mathrm{HCl}(50 \mathrm{~mL})$ and extracted with toluene $(2 \times 35 \mathrm{~mL})$. The combined organic layers were dried $\left(\mathrm{Na}_{2} \mathrm{SO}_{4}\right)$ and concentrated in vacuo. The residue was purified on silica gel in toluene/EtOAc (4:1) in the presence of $3 \% \mathrm{AcOH}$ to produce a $t$-butyl protected product as a dark yellow oil. The resulting product was quenched with a $20 \%$ solution of TFA in water (TFA $\mathrm{H}_{2} \mathrm{O}=4: 1$ ) at $50{ }^{\circ} \mathrm{C}$ over $1 \mathrm{~h}$. After some cooling, most of the solvent evaporated without heating in vacuo, and the mixture was purified with a preparative HPLC reverse-phase column. Sevanol I was isolated from the crude material by RP-HPLC on the polystyrene-based resin LPS-500 (Technosorbent, Moscow, Russia) using a Waters PrepLC 2000 Preparative HPLC System equipped with a Waters 2489 dual-wavelength UV detector. The crude material $(4 \mathrm{~g})$, dissolved in water $(40 \mathrm{~mL})$, was loaded onto the column $(5 \times 25 \mathrm{~cm})$, equilibrated in $95 \%$ of solvent A $(0.1 \%$ TFA in water) and $5 \%$ of solvent B (acetonitrile) at $70 \mathrm{~mL} / \mathrm{min}$ flow rate, and then eluted by linear acetonitrile gradient ( $5 \% \mathrm{~B}-35 \% \mathrm{~B}$ for $60 \mathrm{~min}, 70 \mathrm{~mL} / \mathrm{min}$ ). The elution profile was detected at $254 \mathrm{~nm}$ and $280 \mathrm{~nm}$, fractions (100 mL each) covering the sevanol elution zone were collected and HPLC-tested for sevanol purity. The fractions containing $>98 \%$ (both iso-forms in the summary) pure sevanol I were combined and lyophilized. A light yellow powder of sevanol $\mathrm{I}$, as a mixture of two diastereomers in a ratio 1:3, was obtained $(650 \mathrm{mg}, 15 \%):{ }^{1} \mathrm{H}$ NMR $\left(600 \mathrm{MHz}, \mathrm{D}_{2} \mathrm{O}\right) \delta_{\mathrm{H}}: 7.75(1 \mathrm{H}, \mathrm{s}), 7.01(1 \mathrm{H}, \mathrm{s}), 6.72(1 \mathrm{H}, \mathrm{s}), 6.69(1 \mathrm{H}, J=8.3 \mathrm{~Hz}$, d), $6.62(1 \mathrm{H}, J=2.3 \mathrm{~Hz}, \mathrm{~d}), 6.43(1 \mathrm{H}, J=8.3,2.4 \mathrm{~Hz}, \mathrm{dd}), 5.38(1 \mathrm{H}, J=3.8 \mathrm{~Hz}, \mathrm{~d}), 5.33(1 \mathrm{H}, J=3.6 \mathrm{~Hz}, \mathrm{~d})$, $4.50(1 \mathrm{H}, J=2.4 \mathrm{~Hz}, \mathrm{~d}), 4.09(1 \mathrm{H}, J=2.4 \mathrm{~Hz}, \mathrm{~d}), 3.56(1 \mathrm{H}, J=9.2,5.4,3.8 \mathrm{~Hz}, \mathrm{ddd}), 3.46-3.43(1 \mathrm{H}, \mathrm{m})$, $2.78(1 \mathrm{H}, J=17.3,9.2 \mathrm{~Hz}, \mathrm{dd}), 2.62-2.58(1 \mathrm{H}, \mathrm{m}), 2.51(1 \mathrm{H}, J=17.3,9.4 \mathrm{~Hz}, \mathrm{dd}), 2.24(1 \mathrm{H}, J=17.3$, $5.2 \mathrm{~Hz}, \mathrm{dd}) ;{ }^{13} \mathrm{C}$ NMR $\left(600 \mathrm{MHz}, \mathrm{D}_{2} \mathrm{O}\right) \delta: 175.3,175.1,173.9,173.4,172.7,171.8,166.8,147.6,143.9$, 143.3, 142.8, 141.6, 134.3, 130.8, 123.8, 119.6, 117.4, 116.6, 116.1, 115.3, 72.4, 46.5, 44.0, 42.9, 42.7; HRMS: [M-H] $]^{-}$calcld for $\mathrm{C}_{30} \mathrm{H}_{25} \mathrm{O}_{20} 705.0939[\mathrm{M}-\mathrm{H}]^{-}$found 705.0937.

3.6. Synthesis of Hexamethyl1,1'-((1-(3,4-dihydroxyphenyl)-6,7-dihydroxy-1,2-dihydronaphthalene-2,3dicarbonyl)bis(oxy))bis(propane-1,2,3-tricarboxylate) II

Sevanol I (20 mg, $0.028 \mathrm{mmol})$ was dissolved in $4 \mathrm{M} \mathrm{HCl} / \mathrm{MeOH}(1 \mathrm{~mL})$. The resulting solution was stirred at $-20^{\circ} \mathrm{C}$ for $72 \mathrm{~h}$. The reaction mixture was evaporated, purified on silica gel (EtOAc) and lyophilized to give light-yellow powder II (22 mg, 97\%): Rf (33\% EtOAc/hexane) $0.4 ;{ }^{1} \mathrm{H}$ NMR $\left(800 \mathrm{MHz}\right.$, acetone) $\delta_{\mathrm{H}}: 7.69(1 \mathrm{H}, \mathrm{s}), 6.99(1 \mathrm{H}, \mathrm{s}), 6.73(1 \mathrm{H}, \mathrm{s}), 6.70(1 \mathrm{H}, \mathrm{d}, J=8.1 \mathrm{~Hz}), 6.51(1 \mathrm{H}, \mathrm{d}, J=$ $2.2 \mathrm{~Hz}), 6.45(1 \mathrm{H}, \mathrm{dd}, J=8.2,2.2 \mathrm{~Hz}), 5.43(1 \mathrm{H}, \mathrm{d}, J=4.1 \mathrm{~Hz}), 5.32(1 \mathrm{H}, \mathrm{d}, J=3.9 \mathrm{~Hz}), 4.49(1 \mathrm{H}, \mathrm{d}, J=$ $2.0 \mathrm{~Hz}), 4.02(1 \mathrm{H}, \mathrm{d}, J=2.0 \mathrm{~Hz}), 3.70(3 \mathrm{H}, \mathrm{s}), 3.68(3 \mathrm{H}, \mathrm{s}), 3.66(3 \mathrm{H}, \mathrm{s}), 3.64-3.62(9 \mathrm{H}, \mathrm{m}), 3.57(1 \mathrm{H}, \mathrm{dt}$, $J=9.3,4.7 \mathrm{~Hz}), 3.49(1 \mathrm{H}, \mathrm{dt}, J=9.1,4.5 \mathrm{~Hz}), 2.71-2.65(2 \mathrm{H}, \mathrm{m}), 2.81(1 \mathrm{H}, \mathrm{dd}, J=17.2,9.4 \mathrm{~Hz}), 2.72-$ $2.65(2 \mathrm{H}, \mathrm{m}), 2.50(1 \mathrm{H}, \mathrm{dd}, J=17.2,4.9 \mathrm{~Hz}) ;{ }^{13} \mathrm{C} \mathrm{NMR}\left(800 \mathrm{MHz}, \mathrm{CDCl}_{3}\right) ; \delta: 171.4,171.3,170.5,170.2$, 169.9, 168.1, 167.7, 165.0, 147.9, 139.9, 134.7, 130.3, 123.4, 119.8, 118.6, 116.3, 115.1, 114.5, 78.2, 78.1, 77.9, 71.8, 71.5, 51.8, 46.7, 44.8, 42.9, 42.7, 31.5, 31.3, 29.5; HRMS: $[\mathrm{M}+\mathrm{H}]^{+}$calcld for $\mathrm{C}_{36} \mathrm{H}_{39} \mathrm{O}_{20} 791.2029$ $[\mathrm{M}+\mathrm{H}]^{+}$found 791.2031 . 


\subsection{Synthesis of 2,2'-((1-(3,4-dihydroxyphenyl)-6,7-dihydroxy-1,2-dihydronaphthalene-2,3-dicarbonyl) bis(oxy))disuccinic acid III}

A solution of t-butyl protected caffeic malate ester $9(0.5 \mathrm{~g}, 1.2 \mathrm{mmol})$ in $\mathrm{MeCN}(5 \mathrm{~mL})$ was stirred at $5{ }^{\circ} \mathrm{C}$ in the absence of light while a solution of $\mathrm{FeCl}_{3}(0.49 \mathrm{~g}, 3 \mathrm{mmol})$ in $\mathrm{H}_{2} \mathrm{O}(5 \mathrm{~mL})$ was added dropwise. The reaction mixture, protected from the light, was stirred for $2 \mathrm{~h}$ at $5^{\circ} \mathrm{C}$. The resulting mixture was carefully diluted with $0.1 \mathrm{M} \mathrm{HCl}(20 \mathrm{~mL})$ and extracted with toluene $(2 \times 10 \mathrm{~mL})$. The combined organic layers were dried $\left(\mathrm{Na}_{2} \mathrm{SO}_{4}\right)$ and concentrated in vacuo. The residue was purified on silica gel in toluene/EtOAc $(4: 1)$ in the presence of $4 \% \mathrm{AcOH}$ to produce a $t$-butyl protected product as a dark yellow oil. The resulting product was quenched with a $20 \%$ solution of TFA in water $\left(\right.$ TFA $\left.-\mathrm{H}_{2} \mathrm{O}=4: 1\right)$ at $50{ }^{\circ} \mathrm{C}$ over $45 \mathrm{~min}$. After some cooling, most of the solvent evaporated without heating in vacuo, and the mixture was purified by a preparative HPLC reverse-phase column. The semi-preparative HPLC system Waters 515 was used for this purpose on a tandem of two columns in size $20 \times 250 \mathrm{~mm}$ reversed-phase sorbents 11AD2 11 microns and LPS-500 70 microns (LLC 'Technosorbent', Moscow, Russia) with a linear gradient of acetonitrile (mobile phase A: $0.1 \%$ TFA in water; mobile phase B: acetonitrile; gradient $10-60 \%$ for $60 \mathrm{~min}$ at a flow rate of $10 \mathrm{~mL} / \mathrm{min}$; the profile registration elution was performed by UV absorbance at 254 and $280 \mathrm{~nm})$. A light yellow powder was obtained after lyophilization (124 mg, 17\%): ${ }^{1} \mathrm{H} \mathrm{NMR}\left(600 \mathrm{MHz}, \mathrm{D}_{2} \mathrm{O}\right) \delta_{\mathrm{H}}: 7.69(1 \mathrm{H}, \mathrm{dd}, J=5.3,2.1 \mathrm{~Hz}), 6.92(1 \mathrm{H}, \mathrm{d}$, $J=2.3 \mathrm{~Hz}), 6.65(1 \mathrm{H}, \mathrm{d}, J=2.1 \mathrm{~Hz}), 6.61(1 \mathrm{H}, \mathrm{dd}, J=23.3,2.3 \mathrm{~Hz}), 6.55(1 \mathrm{H}, \mathrm{dd}, J=6.3,2.2 \mathrm{~Hz}), 6.37$ $(1 \mathrm{H}, \mathrm{dd}, J=8.4,2.0 \mathrm{~Hz}), 5.34(1 \mathrm{H}, \mathrm{dd}, J=7.0,4.2 \mathrm{~Hz}), 5.25(1 \mathrm{H}, \mathrm{dd}, J=7.4,3.7 \mathrm{~Hz}), 4.46-4.37(1 \mathrm{H}, \mathrm{m})$, 4.03 - $3.94(1 \mathrm{H}, \mathrm{m}), 2.98-2.88(2 \mathrm{H}, \mathrm{m}), 2.84-2.73(2 \mathrm{H}, \mathrm{m}) ;{ }^{13} \mathrm{C} \mathrm{NMR}\left(600 \mathrm{MHz}, \mathrm{D}_{2} \mathrm{O}\right) \delta: 173.4,172.7$, 173.0, 166.9, 147.3, 143.9, 143.2, 142.8, 141.1, 134.8, 134.4, 130.7, 123.6, 119.8, 119.5, 117.3, 116.5, 116.3, 116.1, 115.3, 115.1, 69.4, 69.2, 46.5, 46.4, 44.5, 44.2, 35.7, 35.4; HRMS: $[\mathrm{M}+\mathrm{H}]^{+}$calcld for $\mathrm{C}_{26} \mathrm{H}_{23} \mathrm{O}_{16}$ $591.0980\left([\mathrm{M}+\mathrm{H}]^{+}\right.$found 591.0982.

\subsection{Synthesis of diethyl 1-(3,4-dihydroxyphenyl)-6,7-dihydroxy-1,2-dihydronaphthalene-2,3-dicarboxylate 11}

The ethyl ester of caffeic acid $10(7.2 \mathrm{mmol}, 1.5 \mathrm{~g})$ was dissolved in acetonitrile $(15 \mathrm{~mL})$ and cooled at $5{ }^{\circ} \mathrm{C}$. A solution of $\mathrm{FeCl}_{3}(18 \mathrm{mmol}, 2.9 \mathrm{~g})$ in water $(30 \mathrm{~mL})$ was carefully added to the resulting solution dropwise at $5{ }^{\circ} \mathrm{C}$ in the absence of light. The resulting mixture was stirred for $2 \mathrm{~h}$. Afterwards, the reaction was diluted with water $(50 \mathrm{~mL})$ and extracted with toluene $(2 \times 30 \mathrm{~mL})$. The combined organic layers were dried $\left(\mathrm{Na}_{2} \mathrm{SO}_{4}\right)$ and evaporated in vacuo. The resulting residue was purified on silica gel eluting with EtOAc/hexane (1:1) to afford dark-yellow powder 11 (0.5 g, 37\%): Rf (50\% EtOAc/hexane) $0.3 ;{ }^{1} \mathrm{H} \mathrm{NMR}\left(600 \mathrm{MHz}\right.$, acetone-d6) $\delta_{\mathrm{H}}: 7.57(1 \mathrm{H}, \mathrm{s}), 6.96(1 \mathrm{H}, \mathrm{s}), 6.71(1 \mathrm{H}, \mathrm{d}, J=8.1$ $\mathrm{Hz}), 6.63(1 \mathrm{H}, \mathrm{s}), 6.51(1 \mathrm{H}, \mathrm{d}, J=2.2 \mathrm{~Hz}), 6.46(1 \mathrm{H}, \mathrm{dd}, J=8.2,2.2 \mathrm{~Hz}), 4.44(1 \mathrm{H}, \mathrm{d}, J=3.3 \mathrm{~Hz}), 4.20-$ $4.12(2 \mathrm{H}, \mathrm{m}), 4.09-3.99(2 \mathrm{H}, \mathrm{m}), 3.89(1 \mathrm{H}, \mathrm{d}, J=3.2 \mathrm{~Hz}), 1.26(3 \mathrm{H}, \mathrm{t}, J=7.1 \mathrm{~Hz}), 1.13(3 \mathrm{H}, \mathrm{t}, J=7.1 \mathrm{~Hz})$; ${ }^{13} \mathrm{C}$ NMR (600 MHz, acetone-d6) $\delta: 147.2,144.7,144.1,143.7,137.1,135.2,130.0,123.9,122.6,118.8$, 116.1, 115.8, 115.0, 114.6, 60.3, 59.9, 47.6, 45.4, 29.4, 29.3, 29.1, 13.6, 13.5; HRMS: [M + H] ${ }^{+}$calcld for $\mathrm{C}_{22} \mathrm{H}_{23} \mathrm{O}_{8} 415.1387[\mathrm{M}+\mathrm{H}]^{+}$found 415.1390 .

\subsection{Synthesis of Epiphyllic Acid IV}

The compound $11(0.2 \mathrm{~g}, 0.46 \mathrm{mmol})$ was dissolved in dioxane $(20 \mathrm{~mL})$, followed by the addition of $4 \mathrm{M} \mathrm{HCl}(10 \mathrm{~mL})$. The resulting solution was stirred for $16 \mathrm{~h}$ under reflux, followed by evaporation in vacuo. The residue was purified with a preparative HPLC reverse-phase column. The semi-preparative HPLC system Waters 515 was used for this purpose on a tandem of two columns in size $20 \times 250 \mathrm{~mm}$ reversed-phase sorbents 11AD2 11 microns and LPS-500 70 microns (LLC 'Technosorbent'. Russia) with a linear gradient of ethanol (mobile phase A: 0.2\% TFA in water; mobile phase B: ethanol; gradient 20-60\% for $60 \mathrm{~min}$ at a flow rate of $10 \mathrm{~mL} / \mathrm{min}$; the profile registration elution was performed by UV absorbance at 254 and $280 \mathrm{~nm})$. A light pink powder was obtained after lyophilization (63 mg, 35\%): ${ }^{1} \mathrm{H}$ NMR $\left(600 \mathrm{MHz}, \mathrm{CDCl}_{3}\right) \delta_{\mathrm{H}}: 7.64(1 \mathrm{H}, \mathrm{s}), 6.94(1 \mathrm{H}, \mathrm{s}), 6.68(1 \mathrm{H}, \mathrm{d}, J=8.3 \mathrm{~Hz}), 6.65(1 \mathrm{H}, \mathrm{s}), 6.59(1 \mathrm{H}$, $\mathrm{d}, J=2.2 \mathrm{~Hz}), 6.43(1 \mathrm{H}, \mathrm{dd}, J=8.3,2.2 \mathrm{~Hz}), 4.41(1 \mathrm{H}, \mathrm{d}, J=3.2 \mathrm{~Hz}), 3.83(1 \mathrm{H}, \mathrm{d}, J=3.1 \mathrm{~Hz}) ;{ }^{13} \mathrm{C} \mathrm{NMR}$ 
$\left(600 \mathrm{MHz}, \mathrm{CDCl}_{3}\right)$ 8: 170.0, 146.4, 143.4, 142.7, 142.3, 139.1, 134.8, 130.0, 123.5, 121.4, 119.1, 116.5, 115.9, 115.6, 114.7, 46.7, 44.3; HRMS: [M + H] ${ }^{+}$calcld for $\mathrm{C}_{18} \mathrm{H}_{15} \mathrm{O}_{8} 359.0761[\mathrm{M}+\mathrm{H}]^{+}$found 359.0762.

\subsection{Electrophysiological Study on Xenopus Laevis Oocytes}

Oocytes were harvested from female frogs anaesthetized with tricaine methane sulfonate (MS222) $(0.17 \%$ solution $)$, and the surgery was performed in an ice bath to avoid heavy bleeding. Defolliculated stage IV and V cells were injected with 2.5 and $10 \mathrm{ng}$ cRNA, synthesized from PCi plasmids containing the rat ASIC1a and rat ASIC3 isoforms, respectively, using the Nanoliter 2000 microinjection system (World Precision Instruments, USA). The injected oocytes were kept for 2-3 days at 17 to $19{ }^{\circ} \mathrm{C}$, and then for up to 5 days at $15^{\circ} \mathrm{C}$ in a ND96 medium containing (in mM) $96 \mathrm{NaCl}, 2 \mathrm{KCl}, 1.8 \mathrm{CaCl}_{2}, 1 \mathrm{MgCl}_{2}$, and 5 HEPES titrated to $\mathrm{pH} 7.4$ with $\mathrm{NaOH}$ supplemented with gentamycin $(50 \mu \mathrm{g} / \mathrm{mL})$. Two-electrode voltage clamp recordings were performed at a holding potential of $-50 \mathrm{mV}$ using a GeneClamp 500 amplifier (Axon Instruments), and the data were filtered at $20 \mathrm{~Hz}$ and digitized at $100 \mathrm{~Hz}$ by an AD converter L780 (LCard, Russia). Microelectrodes were filled with $3 \mathrm{M} \mathrm{KCl}$. The conditioning bath solution was ND96; the $\mathrm{pH}$ was adjusted to 7.4. The activating test solution was constructed based on the ND-96 buffer, in which $5 \mathrm{mM}$ HEPES was replaced with $10 \mathrm{mM}$ MES and $\mathrm{pH}$ was adjusted to 5.5 . A computer-controlled valve system was used to achieve a rapid solution exchange in the recording chamber. A four parameter logistic equation was used for the curve-fitting analysis: $F(x)=\left(\left(a_{1}-a_{2}\right) /(1\right.$ $\left.\left.+\left(\mathrm{x} / \mathrm{x}_{0}\right) n\right)\right)+\mathrm{a}_{2}$, where $\mathrm{x}$ is the concentration of the compound; $\mathrm{F}(\mathrm{x})$ is the response value at a given concentration of the compound; $\mathrm{a}_{1}$ is the control response value (fixed at $100 \%$ ); $\mathrm{x}_{0}$ is the $\mathrm{IC}_{50}$ value; $n$ is the Hill coefficient (slope factor); and $\mathrm{a}_{2}$ is the response value at the maximal inhibition (\% of control).

\subsection{Molecular Modeling}

Ligands preparation and structure-activity relationship (SAR): all of the ligands that were synthesized were also constructed in the Maestro modeling environment (Schrödinger, LLC, New York, NY, 2012). For the SAR analysis, we calculated several molecular descriptors based on the solvent-accessible surface area (SASA) and the Molecular Hydrophobicity Potential (MHP) [42] and the Electrostatic Potential (ELP) formalisms (our in-house software IMPULSE was used). The correlation coefficients were calculated between the compound activity (IC50) and the calculated quantities. These were: the number of carboxyl groups; the formal charge; SASA; the parameters of the MHP distribution over the molecular surface: MHPmax, MHPmin, MHPmean, MHPstd (maximal, minimal, mean and standard deviations of the MHP values, respectively); the hydrophobic and hydrophilic surface areas (with MHP $>0.2$ and $<-0.2$, respectively. The MHP values are given in logP units, where $p$ is the distribution coefficient for the octanol/water binary mixture); ELP is the distribution over the molecular surface statistics: ELPmax, ELPmin, ELPmean, ELPstd (maximal, minimal, mean and standard deviations of the ELP values, respectively; see Table S1).

\subsubsection{Homology Modeling}

Since our experiments were conducted on the rat ASIC1 channels, for further docking studies we had to build homology models of these proteins based on the structures of chicken ASIC1 channels available in the Protein Data Bank (PDB). MODELLER 9.19 [43] was used to produce rASIC1 models in open and closed states, using the PDB structures 4NTW and 5WKU, respectively.

\subsubsection{Molecular Docking}

The prepared rASIC1 models and ligand structures were used for molecular docking in the AutoDock Vina software [44]. Considering that sevanol and its analogues are acidic molecules that are unlikely to occupy the 'classic' acidic pocket, we excluded this area from our investigation of possible docking sites. A $56 \AA$ cubic box centered on the vestibule of rASIC1 was used, which is large enough to allow the sampling of the pore region and several of the surface binding sites. The parameters 
used were as follows: exhaustiveness $=32$; energy_range $=10$; num_modes $=20$. The binding sites' mapping (which is visualized in Figure 4B) was performed using the CavityPlus webserver [45].

\subsection{In Vivo Assay}

Specific pathogen-free outbred ICR male mice (6 to 8 weeks old, weighing 29 to $33 \mathrm{~g}$ ) were obtained from the Animal Breeding Facility of the Branch of the Shemyakin-Ovchinnikov Institute of Bioorganic Chemistry of the Russian Academy of Sciences (Pushchino). The animals were acclimatized for 2 weeks before the experimental procedures, and were kept in two-corridor barrier rooms under a controlled environment: a temperature of 20 to $24{ }^{\circ} \mathrm{C}$, a relative humidity of $30 \%$ to $60 \%$, and a $12 \mathrm{~h}$ light cycle. The animals were housed in Type 3 standard polycarbonate cages $(820 \mathrm{~cm} 2)$ on bedding (LIGNOCEL BK 8/15, JRS, Germany), with ad libitum access to feed (SSNIFF V1534-300, Spezialdiaeten, GmbH) and filtered tap water. The mouse cages were also supplied with material for environmental enrichment, i.e., Mouse House (Techniplast, Italy). Sevanol or the vehicle was administered intravenously, intranasally and orally (30 min before testing).

\subsubsection{Abdominal Constriction Test of Visceral Pain}

The mice were divided into separate groups, and sevanol or saline was administrated (30 min before testing) as described above. Acetic acid in saline $(0.6 \%, 10 \mathrm{~mL} / \mathrm{kg})$ was injected intraperitoneally. The mice were moved into transparent glass cylinders, and the number of writhes was registered for $15 \mathrm{~min}$.

\subsubsection{Complete Freund's Adjuvant-Induced Thermal Hyperalgesia}

The development of the inflammation and thermal hyperalgesia of the paw was induced by the injection of the oil/saline (1:1) CFA emulsion into the dorsal surface of the hind paw of the mice $(20 \mu \mathrm{L} /$ paw $) 24 \mathrm{~h}$ before the measurement. Saline $(20 \mu \mathrm{L})$ was injected into the control mice. The inflamed paw withdrawal latencies to thermal stimulation were measured on a hot plate device (Hot Plate Analgesia Meter, Columbus Instruments) with a set temperature of $53 \pm 0.1^{\circ} \mathrm{C}$ and a cut-off time of $60 \mathrm{~s}$.

The significance of the data was determined by analysis of variance (ANOVA), followed by Tukey's test. Data are presented as mean \pm S.D

\subsubsection{Ethics Statement}

This study strictly complied with the World Health Organization's International Guiding Principles for Biomedical Research Involving Animals. The research was carried out in the Association for Assessment and Accreditation of Laboratory Animal Care International AAALAC accredited organization according to the standards of the Guide for Care and Use of Laboratory Animals (8th edition, Institute for Laboratory Research of Animals). All of the experiments were approved by the Institutional Policy on the Use of Laboratory Animals of the Shemyakin-Ovchinnikov Institute of Bioorganic Chemistry Russian Academy of Sciences (Protocol Number 267/2018; date of approval: 28 February 2019) and by the Institutional Animal Care and Use Committee (IACUC) of the Branch of the Shemyakin-Ovchinnikov Institute of Bioorganic Chemistry of the Russian Academy of Sciences (identification code: 688/19; date of approval: 10 January 2019).

\section{Conclusions}

We obtained novel, interesting and important results for the analgesic molecule sevanol. At first, an effective synthesis scheme was developed both for sevanol and its analogues, which allowed us to perform an investigation of structure-activity relationships. Based on this, we demonstrated an important role of carboxyl groups for the inhibitory activity of sevanol on the ASIC1a and ASIC3 channels. The studied compounds could be arranged in the following order by the strength of the 
action on the channels: s706 (sevanol) > s590 > EA, which correlated well with the number of free carboxyl groups in these molecules. The inactive s788 analog proved the importance of the availability of the carboxyl groups as well. The competition with the RF-amide peptide for sevanol measured in electrophysiological experiments in the whole cell configuration helped us to localize the possible binding site for sevanol in the central vestibule of rASICla using molecular docking studies. Sevanol possesses a strong analgesic effect, and could be bioavailable when administered by non-invasive methods, as was shown in two different in vivo tests. The abdominal constriction and hot-plate tests clearly showed the benefits of the oral method of sevanol administration, which undoubtedly should be preferable for the use of sevanol as a medicine.

Supplementary Materials: The following are available online at http://www.mdpi.com/1424-8247/13/8/163/s1: Supplementary material_NMR.pdf; Table S1: olecular descriptors of the synthesized molecules.

Author Contributions: D.I.O., O.A.B., V.S.K. and S.A.K. designed the experiment; O.A.B., A.N.G. and V.S.K. designed and carried out the synthetic work and the characterization of all of the compounds; D.I.O., A.V. and S.G.K. performed the experiments on the oocytes; A.O.C. and R.G.E. carried out the computational experiments and performed the molecular modeling; V.A.P., Y.A.P., E.R.S., I.A.D., Y.A.A. and S.A.K. were involved in the in vivo tests; O.A.B., D.I.O., Y.A.A., A.O.C., R.G.E. and S.A.K. analyzed the data and wrote the manuscript. All authors have read and agreed to the published version of the manuscript.

Funding: The work was supported by the Russian Science Foundation, grant No. 18-14-00138.

Acknowledgments: We are grateful to Sylvie Diochot (Institut de Pharmacologie Moléculaire et Cellulaire, Valbonne, France) for the PCi plasmid containing cDNA of rat ASIC1a and ASIC3. Authors have greatly appreciated the support of the Basic Research Program at the National Research University Higher School of Economics and Russian Academic Excellence Project '5-100'.

Conflicts of Interest: The authors declare no conflict of interest.

\section{References}

1. Waldmann, R. Proton-gated cation channels-Neuronal acid sensors in the central and peripheral nervous system. In Advances in Experimental Medicine and Biology; Springer: Boston, MA, USA, 2001; Volume 502, pp. 293-304. ISBN 978-1-4757-3401-0.

2. Kellenberger, S.; Schild, L. International Union of Basic and Clinical Pharmacology. XCI. Structure, Function, and Pharmacology of Acid-Sensing Ion Channels and the Epithelial Na+ Channel. Pharmacol. Rev. 2015, 67, 1-35. [CrossRef]

3. Wemmie, J.A.; Askwith, C.C.; Lamani, E.; Cassell, M.D.; Freeman, J.H.; Welsh, M.J. Acid-Sensing Ion Channel 1 Is Localized in Brain Regions with High Synaptic Density and Contributes to Fear Conditioning. J. Neurosci. 2003, 23, 5496-5502. [CrossRef]

4. Xiong, Z.-G.; Zhu, X.-M.; Chu, X.-P.; Minami, M.; Hey, J.; Wei, W.-L.; MacDonald, J.F.; Wemmie, J.A.; Price, M.P.; Welsh, M.J.; et al. Neuroprotection in Ischemia. Cell 2004, 118, 687-698. [CrossRef]

5. Kreple, C.J.; Lu, Y.; Taugher, R.J.; Schwager-Gutman, A.L.; Du, J.; Stump, M.; Wang, Y.; Ghobbeh, A.; Fan, R.; Cosme, C.V.; et al. Acid-sensing ion channels contribute to synaptic transmission and inhibit cocaine-evoked plasticity. Nat. Neurosci. 2014, 17, 1083-1091. [CrossRef]

6. Deval, E.; Noël, J.; Lay, N.; Alloui, A.; Diochot, S.; Friend, V.; Jodar, M.; Lazdunski, M.; Lingueglia, E. ASIC3, a sensor of acidic and primary inflammatory pain. EMBO J. 2008, 27, 3047-3055. [CrossRef]

7. Sluka, K.A.; Price, M.P.; Breese, N.M.; Stucky, C.L.; Wemmie, J.A.; Welsh, M.J. Chronic hyperalgesia induced by repeated acid injections in muscle is abolished by the loss of ASIC3, but not ASIC1. Pain 2003, 106, 229-239. [CrossRef]

8. Price, M.P.; McIlwrath, S.L.; Xie, J.; Cheng, C.; Qiao, J.; Tarr, D.E.; Sluka, K.A.; Brennan, T.J.; Lewin, G.R.; Welsh, M.J. The DRASIC Cation Channel Contributes to the Detection of Cutaneous Touch and Acid Stimuli in Mice. Neuron 2001, 32, 1071-1083. [CrossRef]

9. Fromy, B.; Lingueglia, E.; Sigaudo-Roussel, D.; Saumet, J.L.; Lazdunski, M. Asic3 is a neuronal mechanosensor for pressure-induced vasodilation that protects against pressure ulcers. Nat. Med. 2012, 18, 1205-1207. [CrossRef] 
10. Waldmann, R.; Bassilana, F.; de Weille, J.; Champigny, G.; Heurteaux, C.; Lazdunski, M. Molecular Cloning of a Non-inactivating Proton-gated $\mathrm{Na}+$ Channel Specific for Sensory Neurons. J. Biol. Chem. 1997, 272, 20975-20978. [CrossRef]

11. Dubé, G.R.; Lehto, S.G.; Breese, N.M.; Baker, S.J.; Wang, X.; Matulenko, M.A.; Honoré, P.; Stewart, A.O.; Moreland, R.B.; Brioni, J.D. Electrophysiological and in vivo characterization of A-317567, a novel blocker of acid sensing ion channels. Pain 2005, 117, 88-96. [CrossRef]

12. Voilley, N.; de Weille, J.; Mamet, J.; Lazdunski, M. Nonsteroid Anti-Inflammatory Drugs Inhibit Both the Activity and the Inflammation-Induced Expression of Acid-Sensing Ion Channels in Nociceptors. J. Neurosci. 2001, 21, 8026-8033. [CrossRef] [PubMed]

13. Chen, X.; Qiu, L.; Li, M.; Dürrnagel, S.; Orser, B.A.; Xiong, Z.-G.; MacDonald, J.F. Diarylamidines: High potency inhibitors of acid-sensing ion channels. Neuropharmacology 2010, 58, 1045-1053. [CrossRef] [PubMed]

14. Schmidt, A.; Rossetti, G.; Joussen, S.; Gründer, S. Diminazene Is a Slow Pore Blocker of Acid-Sensing Ion Channel 1a (ASIC1a). Mol. Pharmacol. 2017, 92, 665-675. [CrossRef] [PubMed]

15. Tikhonova, T.B.; Nagaeva, E.I.; Barygin, O.I.; Potapieva, N.N.; Bolshakov, K.V.; Tikhonov, D.B. Monoamine NMDA receptor channel blockers inhibit and potentiate native and recombinant proton-gated ion channels. Neuropharmacology 2015, 89, 1-10. [CrossRef]

16. Escoubas, P.; De Weille, J.R.; Lecoq, A.; Diochot, S.; Waldmann, R.; Champigny, G.; Moinier, D.; Ménez, A.; Lazdunski, M. Isolation of a Tarantula Toxin Specific for a Class of Proton-gated Na + Channels. J. Biol. Chem. 2000, 275, 25116-25121. [CrossRef]

17. Chassagnon, I.R.; McCarthy, C.A.; Chin, Y.K.-Y.; Pineda, S.S.; Keramidas, A.; Mobli, M.; Pham, V.; De Silva, T.M.; Lynch, J.W.; Widdop, R.E.; et al. Potent neuroprotection after stroke afforded by a double-knot spider-venom peptide that inhibits acid-sensing ion channel 1a. Proc. Natl. Acad. Sci. USA 2017, 114, 3750-3755. [CrossRef]

18. Diochot, S.; Baron, A.; Salinas, M.; Douguet, D.; Scarzello, S.; Dabert-Gay, A.-S.; Debayle, D.; Friend, V.; Alloui, A.; Lazdunski, M.; et al. Black mamba venom peptides target acid-sensing ion channels to abolish pain. Nature 2012, 490, 552-555. [CrossRef]

19. Bohlen, C.J.; Chesler, A.T.; Sharif-Naeini, R.; Medzihradszky, K.F.; Zhou, S.; King, D.; Sánchez, E.E.; Burlingame, A.L.; Basbaum, A.I.; Julius, D. A heteromeric Texas coral snake toxin targets acid-sensing ion channels to produce pain. Nature 2011, 479, 410-414. [CrossRef]

20. Diochot, S.; Baron, A.; Rash, L.D.; Deval, E.; Escoubas, P.; Scarzello, S.; Salinas, M.; Lazdunski, M. A new sea anemone peptide, APETx2, inhibits ASIC3, a major acid-sensitive channel in sensory neurons. EMBO J. 2004, 23, 1516-1525. [CrossRef]

21. Osmakov, D.I.; Kozlov, S.A.; Andreev, Y.A.; Koshelev, S.G.; Sanamyan, N.P.; Sanamyan, K.E.; Dyachenko, I.A.; Bondarenko, D.A.; Murashev, A.N.; Mineev, K.S.; et al. Sea Anemone Peptide with Uncommon $\beta$-Hairpin Structure Inhibits Acid-sensing Ion Channel 3 (ASIC3) and Reveals Analgesic Activity. J. Biol. Chem. 2013, 288, 23116-23127. [CrossRef]

22. Kalina, R.; Gladkikh, I.; Dmitrenok, P.; Chernikov, O.; Koshelev, S.; Kvetkina, A.; Kozlov, S.; Kozlovskaya, E.; Monastyrnaya, M. New APETx-like peptides from sea anemone Heteractis crispa modulate ASIC1a channels. Peptides 2018, 104, 41-49. [CrossRef] [PubMed]

23. Kozlov, S.A.; Osmakov, D.I.; Andreev, Y.A.; Koshelev, S.G.; Gladkikh, I.N.; Monastyrnaya, M.M.; Kozlovskaya, E.P.; Grishin, E.V. A sea anemone polypeptide toxin inhibiting the ASIC3 acid-sensitive channel. Russ. J. Bioorganic Chem. 2012, 38, 578-583. [CrossRef] [PubMed]

24. Dubinnyi, M.A.; Osmakov, D.I.; Koshelev, S.G.; Kozlov, S.A.; Andreev, Y.A.; Zakaryan, N.A.; Dyachenko, I.A.; Bondarenko, D.A.; Arseniev, A.S.; Grishin, E.V. Lignan from thyme possesses inhibitory effect on ASIC3 channel current. J. Biol. Chem. 2012, 287, 32993-33000. [CrossRef] [PubMed]

25. Andreev, Y.; Osmakov, D.; Koshelev, S.; Maleeva, E.; Logashina, Y.; Palikov, V.; Palikova, Y.; Dyachenko, I.; Kozlov, S. Analgesic Activity of Acid-Sensing Ion Channel 3 (ASIC3) Inhibitors: Sea Anemones Peptides Ugr9-1 and APETx2 versus Low Molecular Weight Compounds. Mar. Drugs 2018, 16, 500. [CrossRef] [PubMed]

26. Osmakov, D.I.; Koshelev, S.G.; Belozerova, O.A.; Kublitski, V.S.; Andreev, Y.A.; Grishin, E.V.; Kozlov, S.A. Biological Activity of Sevanol and Its Analogues 1. Russ. J. Bioorganic Chem. 2015, 41, 543-547. [CrossRef] 
27. Belozerova, O.A.; Deigin, V.I.; Khrushchev, A.Y.; Dubinnyi, M.A.; Kublitski, V.S. The total synthesis of sevanol, a novel lignan isolated from the thyme plant (Thymus armeniacus). Tetrahedron 2018, 74, 1449-1453. [CrossRef]

28. Miyamae, Y.; Kurisu, M.; Han, J.; Isoda, H.; Shigemori, H. Structure-Activity Relationship of Caffeoylquinic Acids on the Accelerating Activity on ATP Production. Chem. Pharm. Bull. (Tokyo). 2011, 59, 502-507. [CrossRef]

29. Calo, F.; Richardson, J.; Barrett, A.G.M. Total Synthesis of Citrafungin A. J. Org. Chem. 2008, 73, $9692-9697$. [CrossRef]

30. Zhou, T.; Ringbeck, B.; Schebb, N.H.; Scherkenbeck, J. Isolation, total synthesis and quantification of caffeoylisocitric acid, a characteristic ingredient of the superfood amaranth. Tetrahedron 2019, 75, 4479-4485. [CrossRef]

31. Tsegay, S.; Hügel, H.; Rizzacasa, M.A. Formal Total Synthesis of (+)-Citrafungin A. Aust. J. Chem. 2009, 62, 676. [CrossRef]

32. Ballatore, C.; Huryn, D.M.; Smith, A.B. Carboxylic Acid (Bio)Isosteres in Drug Design. ChemMedChem 2013, 8, 385-395. [CrossRef] [PubMed]

33. Fukuyama, Y.; Takahashi, H.; Matsumoto, K.; Ueda, M.; Miyake, Y. Biomimetic Syntheses of Neurotrophic Americanol A and Isoamericanol A by Horseradish Peroxidase (HRP) Catalyzed Oxidative Coupling. Heterocycles 2002, 56, 245. [CrossRef]

34. Brown, T.H.; Blakemore, R.C.; Durant, G.J.; Emmett, J.C.; Ganellin, C.R.; Parsons, M.E.; Rawlings, D.A.; Walker, T.F. Isocytosine H2-receptor histamine antagonists I. Oxmetidine and related compounds. Eur. J. Med. Chem. 1988, 23, 53-62. [CrossRef]

35. Sherwood, T.W.; Askwith, C.C. Endogenous arginine-phenylalanine-amide-related peptides alter steady-state desensitization of ASIC1a. J. Biol. Chem. 2008, 283, 1818-1830. [CrossRef]

36. Osmakov, D.I.; Koshelev, S.G.; Lyukmanova, E.N.; Shulepko, M.A.; Andreev, Y.A.; Illes, P.; Kozlov, S.A. Multiple Modulation of Acid-Sensing Ion Channel 1a by the Alkaloid Daurisoline. Biomolecules 2019, 9, 336. [CrossRef]

37. Bargeton, B.; Iwaszkiewicz, J.; Bonifacio, G.; Roy, S.; Zoete, V.; Kellenberger, S. Mutations in the palm domain disrupt modulation of acid-sensing ion channel 1a currents by neuropeptides. Sci. Rep. 2019, 9, 2599. [CrossRef]

38. Mukhopadhyay, M.; Singh, A.; Sachchidanand, S.; Bera, A.K. Quercetin inhibits acid-sensing ion channels through a putative binding site in the central vestibular region. Neuroscience 2017, 348, 264-272. [CrossRef]

39. Le Bars, D.; Gozariu, M.; Cadden, S.W. Animal models of nociception. Pharmacol. Rev. 2001, 53, 597-652.

40. Mazzuca, M.; Heurteaux, C.; Alloui, A.; Diochot, S.; Baron, A.; Voilley, N.; Blondeau, N.; Escoubas, P.; Gélot, A.; Cupo, A.; et al. A tarantula peptide against pain via ASIC1a channels and opioid mechanisms. Nat. Neurosci. 2007, 10, 943-945. [CrossRef]

41. Osmakov, D.I.; Koshelev, S.G.; Palikov, V.A.; Palikova, Y.A.; Shaykhutdinova, E.R.; Dyachenko, I.A.; Andreev, Y.A.; Kozlov, S.A. Alkaloid Lindoldhamine Inhibits Acid-Sensing Ion Channel 1a and Reveals Anti-Inflammatory Properties. Toxins 2019, 11, 542. [CrossRef]

42. Efremov, R.; Chugunov, A.; Pyrkov, T.; Priestle, J.; Arseniev, A.; Jacoby, E. Molecular Lipophilicity in Protein Modeling and Drug Design. Curr. Med. Chem. 2007, 14, 393-415. [CrossRef] [PubMed]

43. Martí-Renom, M.A.; Stuart, A.C.; Fiser, A.; Sánchez, R.; Melo, F.; Šali, A. Comparative Protein Structure Modeling of Genes and Genomes. Annu. Rev. Biophys. Biomol. Struct. 2000, 29, 291-325. [CrossRef] [PubMed]

44. Trott, O.; Olson, A.J. AutoDock Vina: Improving the speed and accuracy of docking with a new scoring function, efficient optimization, and multithreading. J. Comput. Chem. 2009, 31, 455-461. [CrossRef] [PubMed]

45. Xu, Y.; Wang, S.; Hu, Q.; Gao, S.; Ma, X.; Zhang, W.; Shen, Y.; Chen, F.; Lai, L.; Pei, J. CavityPlus: A web server for protein cavity detection with pharmacophore modelling, allosteric site identification and covalent ligand binding ability prediction. Nucleic Acids Res. 2018, 46, W374-W379. [CrossRef]

(C) 2020 by the authors. Licensee MDPI, Basel, Switzerland. This article is an open access article distributed under the terms and conditions of the Creative Commons Attribution (CC BY) license (http://creativecommons.org/licenses/by/4.0/). 